\title{
Selecting the House-of-Quality-Based Energy Investment Policies for the Sustainable Emerging Economies
}

\author{
Ziyuan Tang ${ }^{1}$ and Hasan Dinçer ${ }^{2, *(D)}$ \\ 1 School of Economics and Management, Xiamen University of Technology, Xiamen 361024, China \\ 2 School of Business, Istanbul Medipol University, Istanbul 34810, Turkey \\ * Correspondence: hdincer@medipol.edu.tr
}

Received: 18 April 2019; Accepted: 17 June 2019; Published: 26 June 2019

check for updates

\begin{abstract}
The purpose of the study is to evaluate the sustainable energy investments based on house of quality. For that, a hybrid decision-making approach to interval type 2 (IT2) fuzzy sets under the hesitancy is proposed. The novelties of the study are to construct an integrated IT2-based modelling and a set of dimensions and criteria for the sustainable energy investments for the emerging countries. The DEMATEL method is used for weighting the customer expectations of sustainable energy investments. The TOPSIS method is applied for ranking the house-of-quality-based investment policies with the technical requirements for the emerging economies. The results show that the capacity issue of energy industry is the most prominent issue for the technical requirements of energy investments. However, it is concluded that increasing communication with the capacity facilities is the most valuable strategy based on the house of quality evaluation. The results are also discussed for further studies and sustainable policies.
\end{abstract}

Keywords: sustainable energy investments; house of quality; emerging economies; interval type-2 fuzzy sets; DEMATEL; TOPSIS; hesitancy

\section{Introduction}

Selecting sustainable investment policies has a key role in effective business strategies. The competitive market environment with global changes in the emerging economies should provide more functional and capable solutions with multidimensional thinking than the conventional business policies [1]. In global competitive market conditions, many customers expect innovative products and services as well as satisfying their needs [2]. The essential solution in conventional market strategies is to widen the communication for selling opportunities with product diversity [3]. However, the active participation of customers in the whole process, from the design to the commercialization, could increase the market potential with full consensus among participants [4,5]. Accordingly, the house of quality is one of the best tools to bring the customer needs and technical requirements together for effective market solutions [6] and facilitate the analysis of effective market dynamics [7].

Similarly, energy industry is also developed under competitive market conditions. Due to this progress, several issues and expectations such as green energy [8], technological effects [9], alternative energy sources [10-12] arise to take advantages of the emerging industries by whole and retail customers. Consequently, sustainable investment policies in the energy industry should be considered in a multidimensional manner by considering customer expectations and technical requirements at the same time. Especially, investment evaluation in emerging economies highly needs both financial and non-financial conditions of a dynamic market for successful business planning. For that, the house-of-quality-based measurements are a key element for evaluating sustainable investment policies multi-dimensionally. 
The concept of energy investment policies is a novel topic for emerging economies [13]. The multidimensional strategies for energy industry are highly related to the sustainable development of emerging economies [14]. Nowadays, the investment policies considering both customer and technical-based factors could be more successful than the conventional strategies focusing on the capacity of the project [15]. Accordingly, the multidimensional approach to energy investment policies brings valuable results for the project's success and the quality improvement with both customer needs and technical requirements is the best way to use the target market and research and development facilities. Thus, the house of quality is an effective tool for understanding the customer and technical factors at the same time $[16,17]$. This study aims to uncover the house-of-quality-based energy investment policies for sustainable development. Customer needs and technical requirements are evaluated for the sustainable energy policies of emerging economies.

Multicriteria decision-making approach is one of the well-known methods for determining the most successful solution among alternative business plans. The multicriteria decision-making models with quality-based factors are generally considered by using the linguistic term sets under the fuzzy environment [18]. Thus, it is possible to provide the choices of decision makers that are experts in the field properly. However, some evaluations could be given in the hesitancy by the experts and this condition should be also handled in the computation process of linguistic term sets. Additionally, the trapezoidal interval type-2 fuzzy sets could provide more accurate and comprehensive results than triangular fuzzy sets [19]. The DEMATEL is one of the best methods to measure the weights as well as the impact and relation map among the criteria. Similarly, the TOPSIS considers the distances of positive and negative ideal solutions for ranking the alternatives more accurately. Accordingly, the DEMATEL is used for weighting the criteria of customer expectations and TOPSIS is applied for ranking the alternatives of technical requirements respectively. Therefore, to the interval type 2 fuzzy sets with the linguistic terms under the hesitancy, a hybrid decision-making approach for the sustainable energy investments in emerging economies is applied.

The paper is organized in five sections. The following section presents the literature review of house of quality, energy investments and multi-criteria decision-making. The third section defines the methodology for the interval type 2 fuzzy sets and linguistic terms under the hesitancy as well as the proposed model. The fourth section illustrates an application on the emerging economies. The final section highlights the discussions and conclusions for further researches.

\section{Literature Review}

Economic issues of energy industry are discussed in the literature extensively. Zafar et al. [13] analyze the increasing economic development with sustainable renewable energy policies. Liang et al. [14] study both economic and other effects by progressive energy production. Keček et al. [20] conclude that energy investments with supported renewable sources influence the national economy for sustainable growth. Economic conditions and country level analysis of energy policies are also studied in recent literature. Hansen et al. [16] evaluate future energy performance by use of green sources in Germany with economic and technical factors. Chuang et al. [21] investigate the wind and solar sources of Taiwan and possible changes in the nuclear ones for the near future. Similarly, technological changes in energy investments are another important topic for the researchers. Lin and Chen [22] analyze the Chinese research and development activities for innovative energy policies. Investments from abroad are an important point of view for sustainable energy policies. Especially, emerging economies are highly related to the foreign direct investment of the energy industry. Accordingly, Chen et al. [23] assess the international trade and renewable energy and their possible relationship to provide policy recommendations.

In the literature, the house of quality is frequently used for analyzing the different issues of production and service industry. For instance, innovation management is studied with the house of quality for the new product development of the USA to highlight that the importance of market expectations should be considered [24]. Additionally, in several studies, the importance of customer 
expectations is conducted with house of quality for the country level analysis [15,17]. However, the cost and financial management, service development [25,26], logistics [27] and health management [28,29] are highly discussed for the multiconditional analysis of house of quality. Moreover, the topic of quality is studied for determining the role of requirements and efficiency in energy industry [30-32]. Especially, Dinçer et al. [33] provide an extended approach to the energy investments of European countries. Quality function deployment is applied with the four-stage analysis, and hesitant fuzzy sets are used for ranking the best investment alternatives.

The multicriteria decision-making approach is a well-known method for ranking the alternatives. In the literature, there are several extensions on decision-making modelling and interval type 2 fuzzy sets are one of the most popular methods for the current literature. However, use of interval type 2 fuzzy DEMATEL is relatively limited in the literature. Abdullah and Zulkifli [34] argue the integration of fuzzy AHP and interval type-2 fuzzy DEMATEL for human resource management. Hosseini and Tarokh [35] use the interval type-2 fuzzy DEMATEL for perceptual computing in the decision-making process. Abdullah and Zulkifli [36] try to understand the causal relationship of knowledge management criteria with a proposed model of interval type-2 fuzzy sets-based DEMATEL. Najib et al. [37] apply the method to the risk factors of coastal erosion including environmental effects. Dinçer et al. [38] propose an integrated method with the interval type-2 fuzzy sets for performance assessment of internationalized firms in the Baltic States. Dinçer and Yuksel [19] evaluate the risk appetite of financial participants in emerging economies by using interval type-2 fuzzy DEMATEL and QUALIFLEX. Tooranloo et al. [39] analyze the factors of sustainable human resource management with the FAHP and IT2-fuzzy DEMATEL. Yüksel et al. [40] use the modified model of interval type-2 fuzzy DEMATEL and TOPSIS for the financial measurement of international energy trade in the European Zone.

Similarly, there are several studies combining the interval type-2 fuzzy sets and TOPSIS method in the literature. Liao [41] develops two TOPSIS material selection models with the interval type-2 fuzzy numbers. Wu et al. [28] use the interval type-2 fuzzy TOPSIS for analyzing large scale group problems based on social network information. Dymova et al. [42] apply the $\alpha$-cuts representation of the interval type-2 fuzzy values for the TOPSIS method. Sang and Liu [43] propose the fractional nonlinear programming problems for fuzzy relative closeness and the analytical solution to IT2 FSs-based TOPSIS model. Zamri and Abdullah [44] apply an optimal preference ranking of an integrated fuzzy TOPSIS and multichoice goal programming in interval type-2 fuzzy sets. Abdullah and Kamal [45] propose the SAW and TOPSIS based on interval type-2 fuzzy sets.

As seen in the recent literature, the development of economics and policy as well as investments are main debates on the energy industry $[14,16,20,21]$. However, there are limited studies of energy dealing with sustainable policy recommendations $[13,22]$. In the current literature, there is no study on the debates of energy policies considering both customer expectations and technical requirements. Furthermore, multicriteria decision-making approach based on interval type 2 fuzzy sets is a novel method for energy industry. Accordingly, this study contributes to the literature by using the integrated method of DEMATEL and TOPSIS based on interval type-2 fuzzy sets. Additionally, another novelty for the energy literature is to apply the house of quality in the energy industry. Thus, it is aimed to construct a new debate for selecting the investment policies by analyzing both quality factors of customer and technical dimensions in the multidimensional manner.

\section{Proposed Model}

A hybrid model including two phases is used for the complex decision-making problem. For that, to utilize the advantages of interval type 2 fuzzy sets into a complex problem and obtain more comprehensive and accurate results from decision makers, the model is constructed by considering the interval type 2 fuzzy sets under the hesitancy of linguistic terms. Microsoft Excel is used for computing the results of IT2 Fuzzy DEMATEL and IT2 Fuzzy TOPSIS respectively. Accordingly, the first stage covers computing the weights of each criterion. IT2 DEMATEL is used for weighting the factors of customer requirements for the sustainable energy investments. The method is entitled as 
decision-making trial and evaluation laboratory. It aims to understand the degrees and ways of mutual effects among the criteria. Moreover, it also computed the relative importance of criteria based on the choices of decision makers.

The second phase of the proposed model continues with the TOPSIS based on interval type 2 fuzzy sets. The method is introduced by Yoon and Hwang [46] and named as Technique for Order Preference by Similarity to Ideal Solution. It focuses on the negative and positive ideal solutions in the ranking process of alternatives. For this reason, calculating the distances from the ideal solution is essential for ranking alternatives in this method. Accordingly, it is aimed to provide more accurate and comprehensive results with the extended approach by using the interval type 2 fuzzy sets under the hesitant linguistic terms. The essentials of interval type 2 fuzzy sets and hesitant linguistic terms are provided in Appendix A. Additionally, the mathematics of the proposed model is detailed in Appendix B respectively. The flowchart of the proposed model is illustrated in Figure 1.

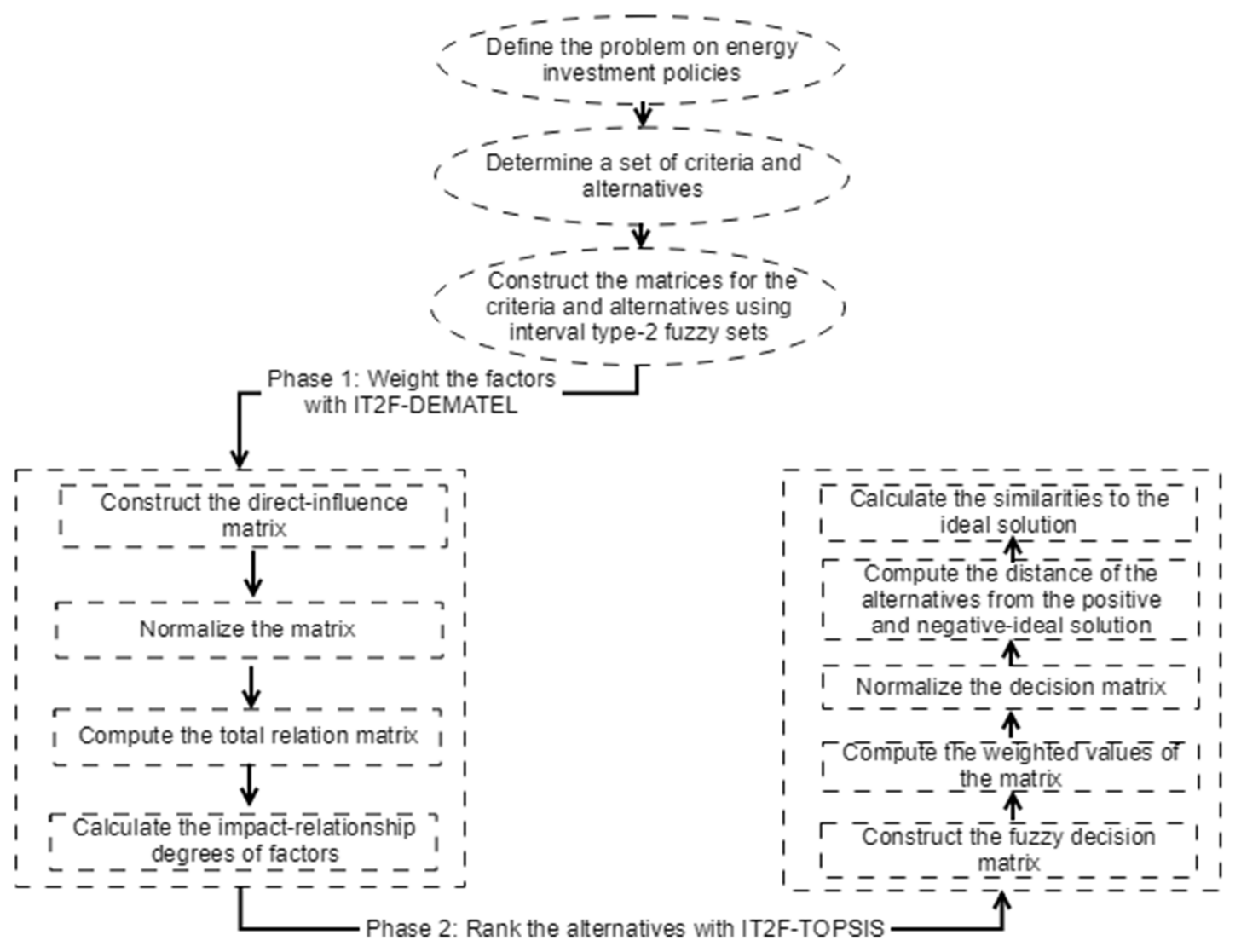

Figure 1. The flowchart of the proposed model. Source: Author's construction.

Figure 1 represents the flowchart of the proposed model and the model is summarized in the following steps:

Step 1: Define the problem of energy investment policy for the sustainable emerging economies. For this aim, the customer's needs and technical requirements are considered to analyze the house-of-quality-based energy investment policies.

Step 2: Determine the criteria for customer expectations and technical factors with the supported literature. The criteria for customer and technical dimensions are represented in Tables 1 and 2. Table 1 represents the customer expectations for increasing energy demand. 
Table 1. Customer expectations for the sustainable investments.

\begin{tabular}{ccc}
\hline Criteria & Definition & Supported Literature \\
\hline Ease of Use (Criterion 1) & $\begin{array}{c}\text { Increase in the speed of the } \\
\text { energy transferring }\end{array}$ & {$[47,48]$} \\
\hline Communication (Criterion 2) & $\begin{array}{c}\text { Continuous assistance with } \\
\text { customer support }\end{array}$ & {$[49,50]$} \\
\hline Physical facilities (Criterion 3) & $\begin{array}{c}\text { Facilities for accessing the } \\
\text { energy sources }\end{array}$ & {$[51]$} \\
\hline Competitive prices (Criterion 4) & $\begin{array}{c}\text { Dynamic pricing in global } \\
\text { energy market }\end{array}$ & {$[50,52]$} \\
\hline Operational convenience (Criterion 5) & $\begin{array}{c}\text { Providing the infrastructure } \\
\text { for the sustainable energy }\end{array}$ \\
\hline
\end{tabular}

Source: Adapted from the supportng literature.

Five criteria are defined based on the literature review. Criterion 1 is ease of use defining the speed of the energy transferring. Second criterion is communication that facilitates the continuous assistance of customer services. The following factor is determined as the physical conditions for accessing energy sources. The fourth criterion is pricing policies to suit the global market trends. The final factor is operational convenience defining the infrastructure of sustainable energy investments.

However, a set of technical requirements of emerging energy policies is determined for the second stage of the house of quality. Technical factors are defined in Table 2.

Table 2. Technical requirements for emerging energy policies.

\begin{tabular}{ccc}
\hline Factors & Definition & Supported Literature \\
\hline Functionality (Alternative 1) & Ease of transaction in the energy sources & {$[33]$} \\
Interaction (Alternative 2) & Considering the customers in the service design & {$[30,31]$} \\
Equipment (Alternative 3) & High-tech tools in the energy investments & {$[33]$} \\
Efficiency (Alternative 4) & Decreasing the costs of energy services & {$[13,21,32]$} \\
Capacity (Alternative 5) & Increase of potential with research and development & {$[22,54]$} \\
\hline
\end{tabular}

Source: Adapted from the supporting literature.

Technical requirements are another dimension for the house of quality. Suggested criteria of emerging energy policies according to the technical requirements are listed as functionality for energy sources (alternative 1), interaction in services with the customers (alternative 2), equipment with high technology (alternative 3), efficiency of energy services (alternative 4) and increase the capacity research and development activities (alternative 5).

Step 3: Appoint the decision makers to obtain the evaluations for the criteria and alternatives. House-of-quality-based evaluations of energy investment policies for the sustainable emerging economies are analyzed by using the scores from the expert team. For that, 3 decision makers are selected for providing the linguistic evaluations of criteria and alternatives. Two experts are from the European Countries and another one is an Asian expert. The decision makers are managers in the international energy firms and have at least ten years of experience in the field of energy policies of emerging economies.

Step 4: Collect the linguistic evaluations of each decision maker for the criteria and alternatives. Seven-point linguistic scales entitled Very very low (VVL), Very low (VL), Low (L), Medium (M), High $(\mathrm{H})$, Very high $(\mathrm{VH})$, Very very high $(\mathrm{VVH})$ are used for the criteria evaluation. Similarly, seven-point scales as Very Poor (VP), Poor (P), Medium Poor (MP), Fair (F), Good (G), Very Good (VG), Best (B) are determined for the alternative evaluations. In this process, individual evaluations of each decision maker are collected to construct the matrices based on interval type 2 fuzzy sets. 
Step 5: Weight the criteria of customer expectations with interval type 2 fuzzy DEMATEL. Linguistic evaluations of each decision maker for the criteria are converted into the fuzzy numbers to employ the initial direct relation matrices and the impact and relation map of customer expectations for the sustainable investments. The application steps of interval type 2 fuzzy DEMATEL are detailed in Appendix B.

Step 6: Rank the alternatives of technical requirement for emerging energy policies. Linguistic evaluations of each decision maker for technical requirement alternatives are collected and the expert choices are illustrated in the fuzzy numbers to measure the relative priorities of decision makers. The application stages and the formulas of interval type 2 fuzzy TOPSIS are provided in Appendix B.

In the next section, the analysis results of the proposed model are determined for sustainable emerging economies, respectively.

\section{Analysis of Results}

A hybrid decision-making approach is proposed for ranking the sustainable energy investments of emerging economies with the house of quality and the type 2 fuzzy sets-based model is applied for evaluating the criteria and alternatives more accurately. For this aim, the DEMATEL and TOPSIS methods are integrated in trapezoidal fuzzy numbers by considering type- 2 fuzzy sets. The analysis is illustrated below.

Initially, the problem of multicriteria decision-making is defined for evaluating the alternatives with an integrated approach. So, it is aimed to analyze the performance results of sustainable energy investment alternatives for emerging economies in the context of quality improvement. The house of quality is adapted to the customer needs and technical requirements of energy investments and a set of criteria and alternatives are proposed for the sustainable energy investments of emerging economies. Three decision makers have been selected for evaluating the criteria and alternatives that define the factors of house of quality. Accordingly, seven point linguistic and fuzzy scales are considered as seen in Table 3.

Table 3. Evaluation scales for criteria.

\begin{tabular}{cc}
\hline Linguistic Scales & Interval Type 2 Fuzzy Numbers \\
\hline Very very low $(\mathrm{VVL})$ & $((0,0.1,0.1,0.2 ; 1,1),(0.05,0.1,0.1,0.15 ; 0.9,0.9))$ \\
Very low $(\mathrm{VL})$ & $((0.1,0.2,0.2,0.35 ; 1,1),(0.15,0.2,0.2,0.3 ; 0.9,0.9))$ \\
Low $(\mathrm{L})$ & $((0.2,0.35,0.35,0.5 ; 1,1),(0.25,0.35,0.35,0.45 ; 0.9,0.9))$ \\
Medium $(\mathrm{M})$ & $((0.35,0.5,0.5,0.65 ; 1,1),(0.4,0.5,0.5,0.6 ; 0.9,0.9))$ \\
High $(\mathrm{H})$ & $((0.5,0.65,0.65,0.8 ; 1,1),(0.55,0.65,0.65,0.75 ; 0.9,0.9))$ \\
Very high (VH) & $((0.65,0.8,0.8,0.9 ; 1,1),(0.7,0.8,0.8,0.85 ; 0.9,0.9))$ \\
Very very high $(\mathrm{VVH})$ & $((0.8,0.9,0.9,1 ; 1,1),(0.85,0.9,0.9,0.95 ; 0.9,0.9))$ \\
\hline
\end{tabular}

The evaluations of each decision maker have been collected for initial direct relation matrix. The expert priorities for the pairwise comparison are presented in Table 4.

After that, the linguistic results have been changed into the fuzzy scales and averaged values are used for the initial relation matrix with the Formulas (A9) and (A10). The results are provided in Table A1.

The second step of proposed model is the normalization procedure of initial direct relation matrix. The normalized values are obtained according to the Equations (A11)-(A13) as seen in Table A2. The following step defines the computation process of total relation matrix. Table $\mathrm{A} 3$ represents the values of total relation matrix by using the Formulas (A14)-(A18). After that, the defuzzification process is applied by the Formulas (A19)-(A22) and the results of each criterion are provided in Table 5. 
Table 4. Linguistic scales of decision makers for relation matrix.

\begin{tabular}{|c|c|c|c|c|c|c|c|c|c|c|c|c|c|c|c|}
\hline \multirow[t]{2}{*}{ Criteria Set } & \multicolumn{3}{|c|}{$\begin{array}{l}\text { Ease of Use } \\
\text { (Criterion 1) }\end{array}$} & \multicolumn{3}{|c|}{$\begin{array}{l}\text { Communication } \\
\text { (Criterion 2) }\end{array}$} & \multicolumn{3}{|c|}{$\begin{array}{l}\text { Physical Facilities } \\
\text { (Criterion 3) }\end{array}$} & \multicolumn{3}{|c|}{$\begin{array}{l}\text { Competitive Prices } \\
\text { (Criterion 4) }\end{array}$} & \multicolumn{3}{|c|}{$\begin{array}{c}\text { Operational Convenience } \\
\text { (Criterion 5) }\end{array}$} \\
\hline & DM1 & DM2 & DM3 & DM1 & DM2 & DM3 & DM1 & DM2 & DM3 & DM1 & DM2 & DM3 & DM1 & DM2 & DM3 \\
\hline Ease of Use (Criterion 1) & - & - & - & M & $\mathrm{H}$ & $\mathrm{H}$ & M & $\mathrm{H}$ & M & $\mathrm{L}$ & M & M & M & $\mathrm{H}$ & $\mathrm{VH}$ \\
\hline Communication (Criterion 2) & M & VH & VH & - & - & - & M & $\mathrm{L}$ & M & $\mathrm{L}$ & M & $\mathrm{H}$ & M & $\mathrm{H}$ & $\mathrm{H}$ \\
\hline Physical facilities (Criterion 3) & $\mathrm{H}$ & $\mathrm{M}$ & $\mathrm{L}$ & M & $\mathrm{H}$ & $\mathrm{H}$ & - & - & - & $\mathrm{L}$ & M & $\mathrm{H}$ & $\mathrm{M}$ & $\mathrm{L}$ & $\mathrm{L}$ \\
\hline Competitive prices (Criterion 4) & $\mathrm{H}$ & $\mathrm{H}$ & M & $\mathrm{H}$ & VH & VH & $\mathrm{H}$ & & & - & - & - & M & $\mathrm{H}$ & M \\
\hline Operational convenience (Criterion 5) & M & $\mathrm{H}$ & $\mathrm{H}$ & M & $\mathrm{H}$ & $\mathrm{H}$ & M & M & M & $\mathrm{L}$ & $\mathrm{L}$ & M & - & - & - \\
\hline
\end{tabular}

Source: Authors' calculations.

Table 5. Defuzzified total relation matrix.

\begin{tabular}{|c|c|c|c|c|c|}
\hline Criteria Set & $\begin{array}{l}\text { Ease of Use } \\
\text { (Criterion 1) }\end{array}$ & $\begin{array}{c}\text { Communication } \\
\text { (Criterion 2) }\end{array}$ & $\begin{array}{l}\text { Physical Facilities } \\
\text { (Criterion 3) }\end{array}$ & $\begin{array}{l}\text { Competitive Prices } \\
\text { (Criterion 4) }\end{array}$ & $\begin{array}{c}\text { Operational Convenience } \\
\text { (Criterion 5) }\end{array}$ \\
\hline Ease of Use (Criterion 1) & 0.53 & 0.71 & 0.65 & 0.57 & 0.69 \\
\hline Communication (Criterion 2) & 0.69 & 0.54 & 0.61 & 0.58 & 0.66 \\
\hline Physical facilities (Criterion 3) & 0.63 & 0.67 & 0.47 & 0.56 & 0.60 \\
\hline Competitive prices (Criterion 4) & 0.74 & 0.80 & 0.72 & 0.50 & 0.73 \\
\hline Operational convenience (Criterion 5) & 0.66 & 0.68 & 0.61 & 0.55 & 0.50 \\
\hline
\end{tabular}

Source: Authors' calculations. 
In the next step, each row (r) and column (y) of defuzzified total relation matrix are aggregated to provide the influence degrees and importance results of criteria. Figure 2 shows the values of $(r+y)$, $(\mathrm{r}-\mathrm{y})$ and weighting results.

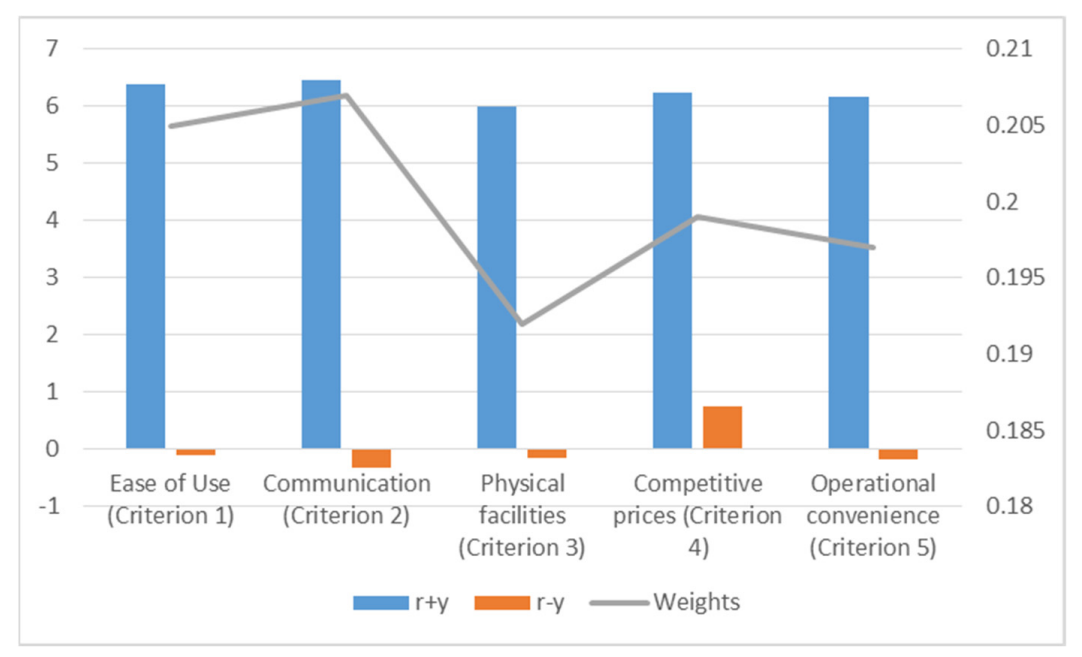

Figure 2. The values of $(r+y)$ and $(r-y)$ and weighting results. Source: Authors' calculations.

The importance degrees of each criterion are measured by using the values of $(r+y)$ and the values of $(\mathrm{r}-\mathrm{y})$ demonstrate the influence degrees of each criterion as seen in Figure 2. According to the weighting results, communication (criterion 2) is the most important factor with 20.7 percentage between the criterion set while physical facilities (criterion 3) with 19.7 percentage has the weakest importance of the sustainable energy investments according to the customer expectations. Furthermore, communication (criterion 2) has the least value of $(r-y)$ with -0.32 and it means that communication is the most influenced factor among the factors of customer expectations for sustainable investments. Competitive prices (criterion 4) has the maximum value of $(r-y)$ with 0.74 , and so it is selected as the most influencing criterion between customer expectations. This is also the first stage of house of quality defining the customer needs for sustainable energy investments.

Additionally, the impact and relation map among criteria is also provided with the results of the IT2 fuzzy DEMATEL. The averaged value of defuzzified total relation matrix is defined as a threshold value for defining the possible impact on criteria. The value of the threshold is determined as 0.625 and the higher values than the threshold indicate there is an impact on the other criteria. If both criteria exceeds the threshold in the matrix, it is assumed that there is a mutual relationship between them. The impact and relation directions of each criterion are seen in Figure 3.

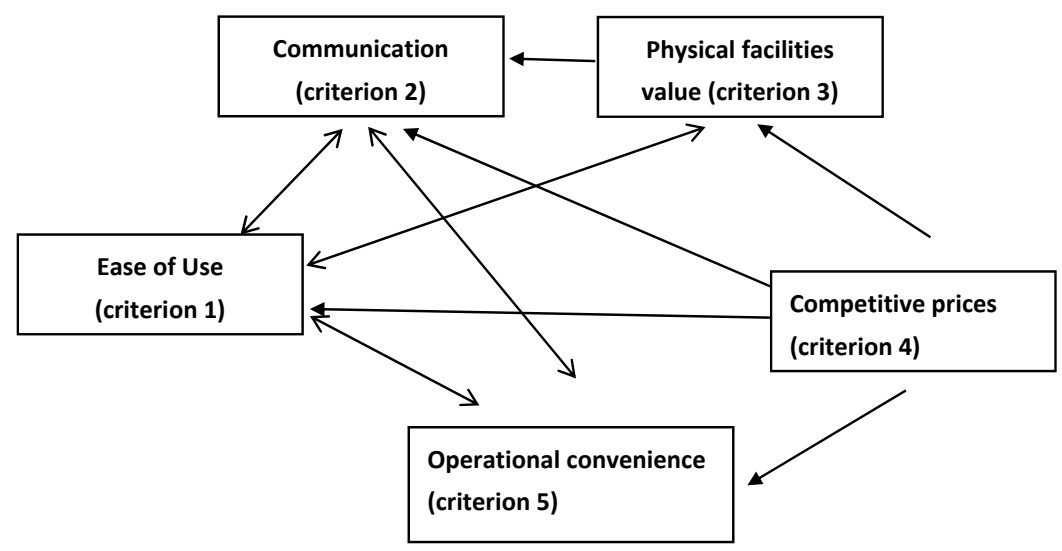

Figure 3. Impact and relation map of customer expectations for sustainable investments. Source: Authors' construction. 
Figure 3 illustrates the impact and relation map of customer expectations for sustainable investments. Thus, it is possible to understand the directions of influences for customer expectation criteria more accurately. According to the results, ease of use (criterion 1) is the most influenced criterion among the criteria set of customer expectations for sustainable investments, while competitive prices (criterion 4) is the most influencing factor between the criteria. Accordingly, there is no impact on competitive prices to determine the customer expectations for sustainable investments. As a result, ease of use should be developed by considering the communication, physical facilities and operational convenience gradually. The competitive prices are also frequently observed in the fair competitive market conditions to follow the customer expectations with the high-quality standards.

In the second stage of the proposed model, the linguistic evaluations for alternatives are analyzed for sustainable energy investments. Alternatives represent the technical requirements of emerging energy policies and are ranked by considering the house-of-quality-based evaluations in the multidimensional manner. Table 6 presents the choices for evaluating the alternatives.

Table 6. Evaluation scales for alternatives.

\begin{tabular}{cc}
\hline Linguistic Scales & Interval Type 2 Fuzzy Numbers \\
\hline Very Poor (VP) & $((0,0,0,0.1 ; 1,1),(0,0,0,0.05 ; 0.9,0.9))$ \\
Poor (P) & $((0,0.1,0.1,0.3 ; 1,1),(0.05,0.1,0.1,0.2 ; 0.9,0.9))$ \\
Medium Poor (MP) & $((0.1,0.3,0.3,0.5 ; 1,1),(0.2,0.3,0.3,0.4 ; 0.9,0.9))$ \\
Fair (F) & $((0.3,0.5,0.5,0.7 ; 1,1),(0.4,0.5,0.5,0.6 ; 0.9,0.9))$ \\
Good (G) & $((0.5,0.7,0.7,0.9 ; 1,1),(0.6,0.7,0.7,0.8 ; 0.9,0.9))$ \\
Very Good (VG) & $((0.7,0.9,0.9,1 ; 1,1),(0.8,0.9,0.9,0.95 ; 0.9,0.9))$ \\
Best (B) & $((0.9,1,1,1 ; 1,1),(0.95,1,1,1 ; 0.9,0.9))$ \\
& Source: $[55,56]$.
\end{tabular}

Table 7 provides the linguistic evaluations of 3 decision makers for the decision matrix.

The decision matrix is constructed based on interval type 2 fuzzy sets under the linguistic hesitant terms by using the Formulas (A23) and (A24). The results are seen in Table A4.

According to the step 7 of IT2 fuzzy TOPSIS, the defuzzified decision matrix is constructed by the Equations (A25)-(A28) and the results are determined in Table 8.

The following step is the weighted decision matrix. The weighted scores are obtained by using the values from the DEMATEL results as seen in Table 9.

The positive and negative ideal solutions of each criterion are represented in Figure 4.

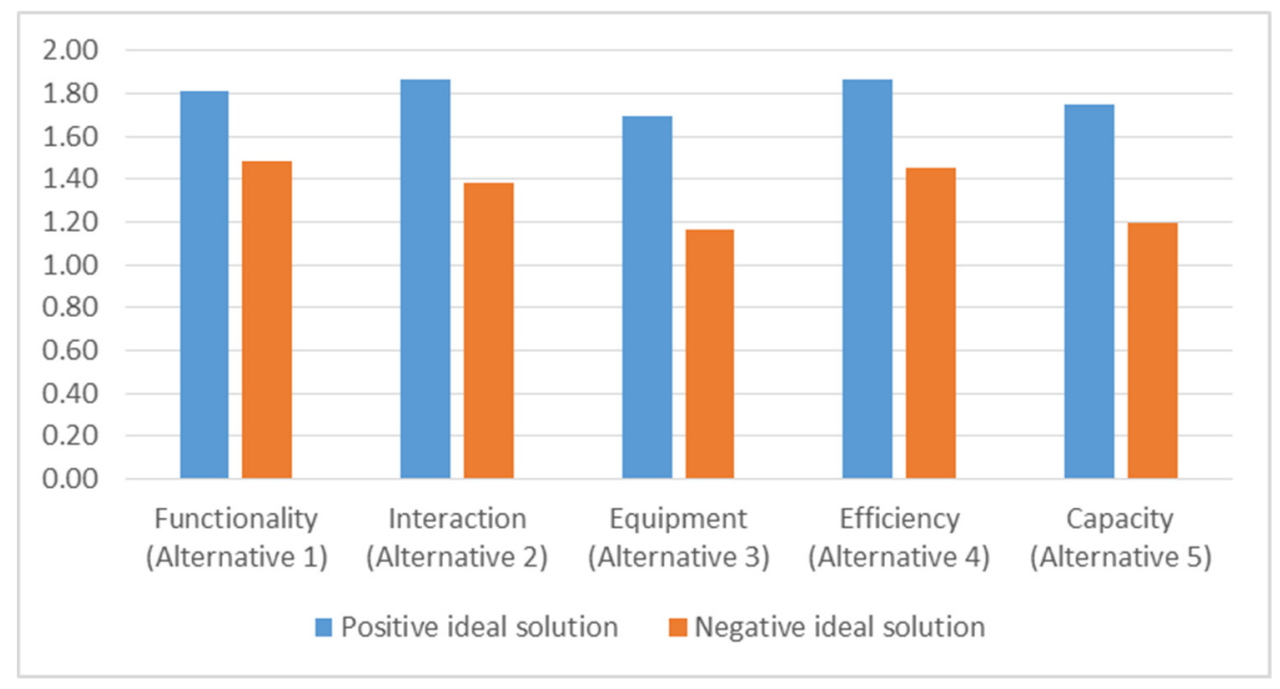

Figure 4. Positive and negative ideal solutions for alternatives. Source: Authors' calculations. 
Table 7. Linguistic scales of decision makers for decision matrix.

\begin{tabular}{|c|c|c|c|c|c|c|c|c|c|c|c|c|c|c|c|}
\hline \multirow[t]{2}{*}{ Criteria/Alternatives } & \multicolumn{3}{|c|}{$\begin{array}{l}\text { Functionality } \\
\text { (Alternative 1) }\end{array}$} & \multicolumn{3}{|c|}{$\begin{array}{c}\text { Interaction } \\
\text { (Alternative 2) }\end{array}$} & \multicolumn{3}{|c|}{$\begin{array}{c}\text { Equipment } \\
\text { (Alternative 3) }\end{array}$} & \multicolumn{3}{|c|}{$\begin{array}{c}\text { Efficiency } \\
\text { (Alternative 4) }\end{array}$} & \multicolumn{3}{|c|}{$\begin{array}{c}\text { Capacity } \\
\text { (Alternative 5) }\end{array}$} \\
\hline & DM1 & DM2 & DM3 & DM1 & DM2 & DM3 & DM1 & DM2 & DM3 & DM1 & DM2 & DM3 & DM1 & DM2 & DM3 \\
\hline Ease of Use (Criterion 1) & VG & G & $\mathrm{B}$ & G & VG & VG & G & VG & G & F & G & G & $\mathrm{F}$ & G & VG \\
\hline Communication (Criterion 2) & G & G & G & $\mathrm{F}$ & G & $\mathrm{F}$ & $\mathrm{F}$ & $\mathrm{F}$ & $\mathrm{F}$ & $\mathrm{F}$ & $\mathrm{F}$ & $\mathrm{F}$ & VG & VG & VG \\
\hline Physical facilities (Criterion 3) & G & $\mathrm{B}$ & VG & F & G & G & $\mathrm{F}$ & $\mathrm{F}$ & $\mathrm{F}$ & MP & $\mathrm{F}$ & $\mathrm{F}$ & $\mathrm{F}$ & G & G \\
\hline Competitive prices (Criterion 4) & VG & $\mathrm{B}$ & VG & $\mathrm{F}$ & G & G & $\mathrm{F}$ & G & G & G & G & G & G & VG & $\mathrm{B}$ \\
\hline Operational convenience (Criterion 5) & $\mathrm{F}$ & $\mathrm{F}$ & $\mathrm{F}$ & F & $\mathrm{F}$ & $\mathrm{F}$ & $\mathrm{F}$ & G & G & FL & $\mathrm{F}$ & $\mathrm{F}$ & G & $\mathrm{B}$ & VG \\
\hline
\end{tabular}

Source: Authors' calculations.

Table 8. Defuzzified decision matrix.

\begin{tabular}{cccccc}
\hline Criteria/Alternatives & $\begin{array}{c}\text { Functionality } \\
\text { (Alternative 1) }\end{array}$ & $\begin{array}{c}\text { Interaction } \\
\text { (Alternative 2) }\end{array}$ & $\begin{array}{c}\text { Equipment } \\
\text { (Alternative 3) }\end{array}$ & $\begin{array}{c}\text { Efficiency } \\
\text { (Alternative 4) }\end{array}$ & $\begin{array}{c}\text { Capacity } \\
\text { (Alternative 5) }\end{array}$ \\
\hline Ease of Use (Criterion 1) & 8.86 & 8.46 & 8.45 & 7.27 \\
Communication (Criterion 2) & 7.87 & 7.49 & 6.67 & 6.67 \\
Physical facilities (Criterion 3) & 8.86 & 7.58 & 6.67 & 7.86 \\
Competitive prices (Criterion 4) & 9.36 & 7.58 & 7.27 & 7.07 \\
Operational convenience (Criterion 5) & 6.67 & 7.15 & 6.67 & 6.07 \\
\hline
\end{tabular}

Source: Authors' calculations.

Table 9. Weighted decision matrix.

\begin{tabular}{|c|c|c|c|c|c|}
\hline Criteria/Alternatives & $\begin{array}{l}\text { Functionality } \\
\text { (Alternative 1) }\end{array}$ & $\begin{array}{c}\text { Interaction } \\
\text { (Alternative 2) }\end{array}$ & $\begin{array}{c}\text { Equipment } \\
\text { (Alternative 3) }\end{array}$ & $\begin{array}{c}\text { Efficiency } \\
\text { (Alternative 4) }\end{array}$ & $\begin{array}{c}\text { Capacity } \\
\text { (Alternative 5) }\end{array}$ \\
\hline Ease of Use (Criterion 1) & 1.81 & 1.73 & 1.73 & 1.49 & 1.61 \\
\hline Communication (Criterion 2) & 1.63 & 1.55 & 1.38 & 1.38 & 1.87 \\
\hline Physical facilities (Criterion 3) & 1.70 & 1.45 & 1.28 & 1.16 & 1.39 \\
\hline Competitive prices (Criterion 4) & 1.87 & 1.51 & 1.45 & 1.57 & 1.77 \\
\hline Operational convenience (Criterion 5) & 1.32 & 1.41 & 1.32 & 1.20 & 1.75 \\
\hline
\end{tabular}


Figure 4 shows that interaction (alternative 2) and efficiency (alternative 4 ) have the maximum values with 1.87 for the positive ideal solution while equipment (alternative 3 ) has the minimum value with 1.16 for the negative ideal solution. However, the values of D+ and D- as well as the closeness coefficient should be computed to obtain the final results by the Equations (A29)-(A32). The results are illustrated in Figure 5.

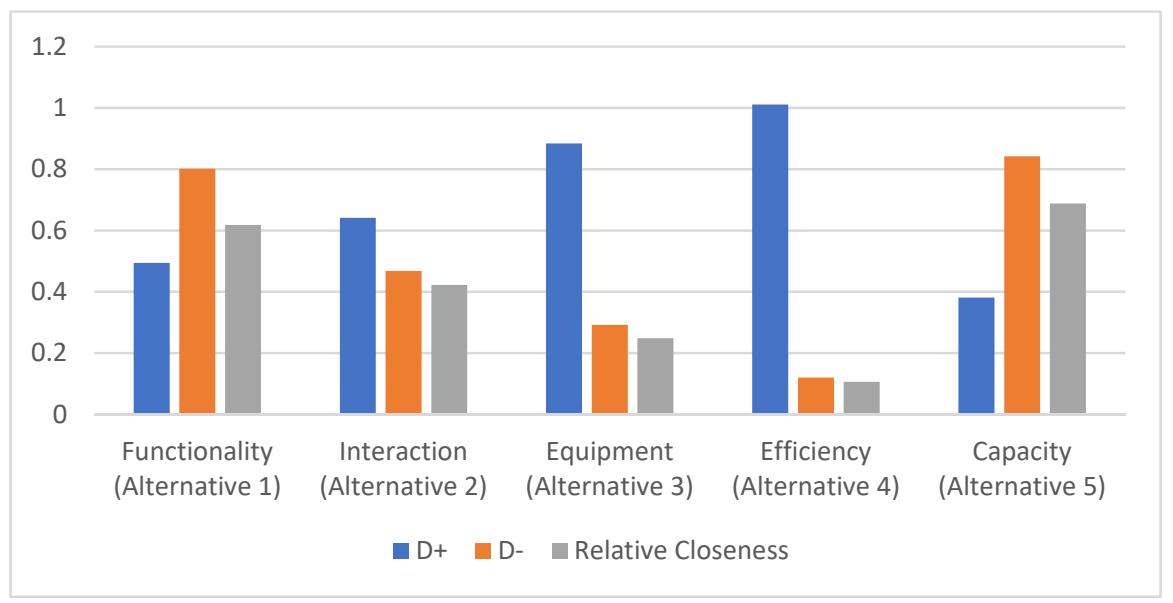

Figure 5. The values of D+, D- and relative closeness of alternatives. Source: Authors' calculations.

The distances from the positive and negative ideal solutions are calculated by the values of D+ and $\mathrm{D}_{-}$, and the values of relative closeness defining the closeness coefficient are computed for ranking alternatives. Figure 5 represents that efficiency (alternative 4) has the extreme results for both the distances from the positive and negative ideal solutions. However, capacity (alternative 5) has the maximum value of relative closeness with 0.688 whereas efficiency has the minimum value with 0.106 among the technical requirements for emerging energy policies.

In Figure 6, the ranking results demonstrate that capacity (alternative 5) has a first seat among the technical requirements of emerging energy policies as the efficiency (alternative 4) is listed in the last. Therefore, the house-of-quality-based analysis with the proposed model could provide comprehensive results by considering the multidimensional factors including the customer needs and technical requirements of sustainable energy investments. Overall results present a clear evidence for the emerging energy industries that capacity is the most prominent technical requirement while communication is the most important factor among the customer needs for sustainable investment policies according to the house-of-quality-based multi criteria decision-making approach.

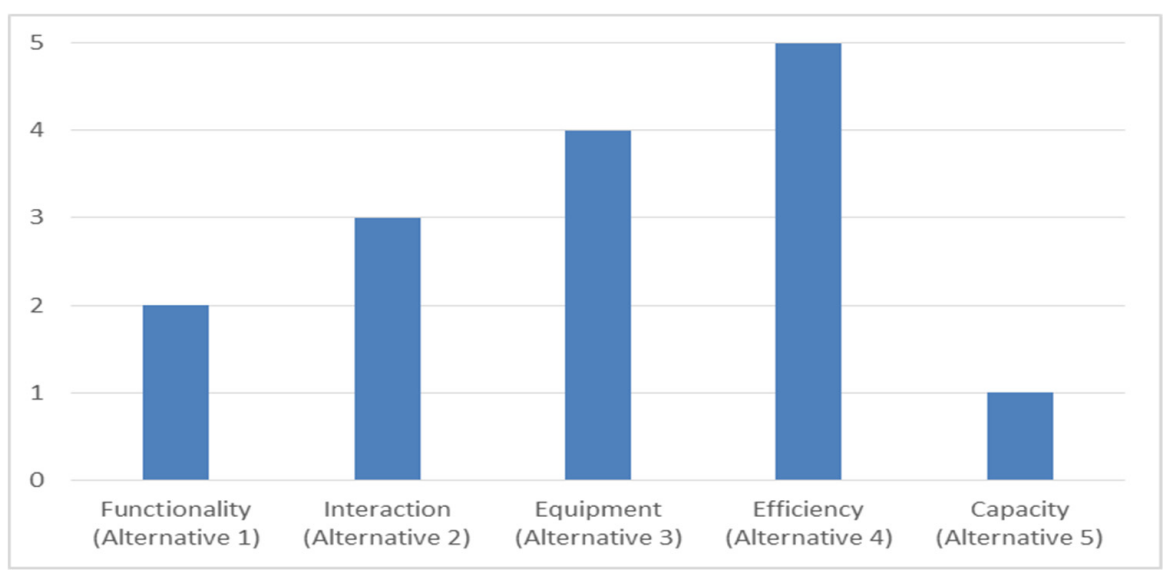

Figure 6. Ranking results of technical requirements. Source: Authors' calculations. 


\section{Discussion and Conclusions}

Investment decision is an extensive topic on the financial and cost management. Most of business strategies depends on both financial and non-financial determinants of the global market environment. Especially, it is difficult to measure the qualitative parameters of investment choices, but it could be one of the prominent issues for successful business plans. There are several studies in the literature for analyzing the capital budgeting and investment decision; however, applying business analytics to the investment decision by using multi-criteria decision-making provides a new point of view to complex financial analysis [57].

Global changes in the technological infrastructure and steady developments of customer expectations need the revising of corporate strategies [58]. Especially, the priorities for sustainable investment decision depend on economic and technical conditions as well as customer expectations. With respect to this, multidimensional evaluation of quality management could ease to get competitive advantages among global business strategies. Accordingly, the house of quality provides for both customer needs and technical requirements in the multidimensional manner. For that, the house-of-quality-based evaluations are used for attaining more precious and appropriate results for sustainable investment decision-making $[59,60]$.

One of the most important priorities for international energy firms is to select the investment strategies based on internal and external customer expectations. So, firms should follow the current issues of energy industry closely to create more valuable solutions for the success of investment. Especially, renewable energy policies, performance and cost management, research and development activities, and foreign investments are among the most recent problems of energy investments. Besides, the expectations of end-users and commercial customers are also valuable for sustainable energy policies. Thus, investment decisions with the house of quality approach could give more constraint results for the multidimensional market environment.

In the study, an integrated decision-making model is proposed for selecting the best alternatives of technical requirements of emerging energy policies. Additionally, the house-of-quality-based multi-criteria decision-making model could give both customer and technical factors at the same time. 3 Decision makers are appointed to give their priorities for each criterion and alternative. In the literature, fuzzy-based evaluations are generally applied with a number of decision makers between 3 and 5 [61-63]. However, number of experts could be increased for the future studies. Accordingly, interval type-2 fuzzy sets-based decision-making models provides more comprehensive results for the complex decision-making problems of real-world applications. Thus, it aims to provide an integrated approach to the energy investment policies for sustainable emerging economies.

The findings demonstrate that communication is the most prominent criterion in customer expectations whereas physical conditions have a relative weak importance among the first dimension of house of quality. Accordingly, Ball et al. [64] highlight the role of communication in customer needs by explaining the effects of communication and trust on customer loyalty. Similarly, Ford [65] discusses the personalized service communication for customer expectations with the interactions of service providers.

However, the perceived benefits coming from sustainable energy investments are related with willingness to pay for sustainable investment expansion. Therefore, information about the benefits offered from sustainable investments should be communicated to customers [66]. Furthermore, providing information about the positive contribution of green energy in enhancing the environment and life quality can prove beneficial in motivating future customers [67].

Additionally, capacity of energy sources reflects on the technical requirements most dominantly. Accordingly, Tsili and Papathanassiou [68] examine the important technical requirements including the active and reactive power regulations for wind farms. Kondziella and Bruckner [69] emphasize the flexibility requirements of renewable energy-based electricity systems. Alternatively, Yam and Hassan [70] argue the dramatic improvements in LED technology capacity and performance with the innovative and sustainable investment policies. 
Overall results show that the capacity increase should be actively managed by considering the effective communication in the marketplace. Thus, policy makers should strictly consider the continuous cooperation and timely feedback for developing customer expectations [71]. Moreover, other technical requirements entitled functionality, interaction, equipment and efficiency could be improved for the sustainable increase of quality management [72,73].

The novelty of this study is to uncover the energy investment policies based on customer needs and technical requirements at the same time by using the house of quality for emerging economies. Another novelty is to propose an integrated method with interval type-2 fuzzy sets for analyzing sustainable energy investments. Thus, it is purposed to provide a new debate for analyzing the house-of-quality-based energy investment policies for sustainable emerging economies by using an IT2-based hybrid hesitant decision-making approach. The limitation of this study is to evaluate the energy investments of emerging economies and to measure the customer needs for ranking the technical requirements. The study could be widened by using different types of multicriteria decision-making models such as VIKOR and MOORA. Alternatively, country-level analysis could be also applied by ranking the performances of emerging economies for comparative analysis.

Author Contributions: All authors contributed equally to the manuscript.

Funding: The study was supported by "Social Science Foundation of Fujian Province of China (Grant No.FJ2018C037)" and "Education and Scientific Research Project for Young Teachers in Fujian Province of China" (GrantNo.JAS170344).

Conflicts of Interest: The authors declare that there is no conflict of interest.

\section{Appendix A. IT2 and Linguistic Term Sets under the Hesitancy}

Interval type-2 fuzzy sets $(\widetilde{A})$ are generally used for the type-2 membership function $\mu_{\widetilde{A}(x, u)}$ and presented with the Formula (A1).

$$
\widetilde{A}=\left\{\left((x, u), \mu_{\widetilde{A}(x, u)}\right) \mid \forall_{x} \in X, \forall_{u} \in J_{x} \subseteq[0,1]\right\}, \text { or } \widetilde{A}=\int_{x \in X} \int_{u \in J_{x}} \mu_{\widetilde{A}}(x, u) /(x, u) J_{x} \subseteq[0,1]
$$

where $\iint$ is the union of all $x$ and $u$.

The interval type-2 fuzzy set is

$$
\widetilde{A}=\int_{x \in X} \int_{u \in J_{x}} 1 /(x, u) \subseteq[0,1]
$$

where the membership function $J_{x}$ is equal to 1.

However, the upper and lower trapezoidal membership functions should be defined for the trapezoidal membership function with the Formula (A3)

$$
\begin{aligned}
& \widetilde{A}_{i}=\left(\widetilde{A}_{i}^{U}, \widetilde{A}_{i}^{L}\right) \\
& =\left(\left(a_{i 1}^{U}, a_{i 2}^{U}, a_{i 3}^{U}, a_{i 4}^{U} ; H_{1}\left(\widetilde{A}_{i}^{U}\right), H_{2}\left(\widetilde{A}_{i}^{U}\right)\right),\left(a_{i 1}^{L}, a_{i 2}^{L}, a_{i 3}^{L}, a_{i 4}^{L} ; H_{1}\left(\widetilde{A}_{i}^{L}\right), H_{2}\left(\widetilde{A}_{i}^{L}\right)\right)\right)
\end{aligned}
$$

where $\widetilde{A}_{i}^{U}$ is the upper and $\widetilde{A}_{i}^{L}$ is the lower trapezoidal membership function and $a_{i 1}^{U} \ldots a_{i 4}^{L}$ are the reference values.

The type-1 fuzzy sets are presented by $\widetilde{A}_{i}^{U}$ and $\widetilde{A}_{i}^{L} \cdot H_{j}\left(\widetilde{A}_{i}^{U}\right)$ and $H_{j}\left(\widetilde{A}_{i}^{L}\right)$ are the membership values. 
On the other side, the essential computations of interval type-2 fuzzy sets are illustrated below

$$
\begin{aligned}
& \widetilde{A_{1}} \oplus \widetilde{A_{2}}=\left(\widetilde{A_{1}^{U}}, \widetilde{A_{1}^{L}}\right) \oplus\left(\widetilde{A_{2}^{U}}, \widetilde{A_{2}^{L}}\right) \\
& =\left(\left(a_{11}^{U}+a_{21}^{U}, a_{12}^{U}+a_{22^{\prime}}^{U}, a_{13}^{U}+a_{23}^{U}, a_{14}^{U}\right.\right. \\
& \left.+a_{24}^{U} ; \min \left(H_{1}\left(\widetilde{A}_{1}^{U}\right), H_{1}\left(\widetilde{A}_{2}^{U}\right)\right), \min \left(H_{2}\left(\widetilde{A}_{1}^{U}\right), H_{2}\left(\widetilde{A}_{2}^{U}\right)\right)\right),\left(a_{11}^{L}\right. \\
& +a_{21}^{L}, a_{12}^{L}+a_{22}^{L}, a_{13}^{L}+a_{23}^{L}, a_{14}^{L} \\
& \left.\left.+a_{24}^{L} ; \min \left(H_{1}\left(\widetilde{A}_{1}^{L}\right), H_{1}\left(\widetilde{A}_{2}^{L}\right)\right), \min \left(H_{2}\left(\widetilde{A}_{1}^{L}\right), H_{2}\left(\widetilde{A}_{2}^{L}\right)\right)\right)\right) \\
& \widetilde{A_{1}} \ominus \widetilde{A_{2}}=\left(\widetilde{A_{1}^{U}}, \widetilde{A_{1}^{L}}\right) \ominus\left(\widetilde{A}_{2}^{U}, \widetilde{A}_{2}^{L}\right) \\
& =\left(\left(a_{11}^{U}-a_{24}^{U}, a_{12}^{U}-a_{23^{\prime}}^{U}, a_{13}^{U}-a_{22}^{U}, a_{14}^{U}\right.\right. \\
& \left.-a_{21}^{U} ; \min \left(H_{1}\left(\widetilde{A}_{1}^{U}\right), H_{1}\left(\widetilde{A}_{2}^{U}\right)\right), \min \left(H_{2}\left(\widetilde{A}_{1}^{U}\right), H_{2}\left(\widetilde{A}_{2}^{U}\right)\right)\right),\left(a_{11}^{L}\right. \\
& -a_{24}^{L}, a_{12}^{L}-a_{23}^{L}, a_{13}^{L}-a_{22}^{L}, a_{14}^{L} \\
& \left.\left.-a_{21}^{L} ; \min \left(H_{1}\left(\widetilde{A}_{1}^{L}\right), H_{1}\left(\widetilde{A}_{2}^{L}\right)\right), \min \left(H_{2}\left(\widetilde{A}_{1}^{L}\right), H_{2}\left(\widetilde{A}_{2}^{L}\right)\right)\right)\right) \\
& \widetilde{A_{1}} \otimes \widetilde{A}_{2}=\left(\widetilde{A_{1}^{U}}, \widetilde{A}_{1}^{L}\right) \otimes\left(\widetilde{A}_{2}^{U}, \widetilde{A}_{2}^{L}\right) \\
& =\left(\left(a_{11}^{U} \times a_{21}^{U}, a_{12}^{U} \times a_{22}^{U}, a_{13}^{U} \times a_{23}^{U}, a_{14}^{U}\right.\right. \\
& \left.\times a_{24}^{U} ; \min \left(H_{1}\left(\widetilde{A}_{1}^{U}\right), H_{1}\left(\widetilde{A}_{2}^{U}\right)\right), \min \left(H_{2}\left(\widetilde{A}_{1}^{U}\right), H_{2}\left(\widetilde{A}_{2}^{U}\right)\right)\right),\left(a_{11}^{L}\right. \\
& \times a_{21}^{L}, a_{12}^{L} \times a_{22}^{L}, a_{13}^{L} \times a_{23}^{L}, a_{14}^{L} \\
& \left.\left.\times a_{24}^{L} ; \min \left(H_{1}\left(\widetilde{A}_{1}^{L}\right), H_{1}\left(\widetilde{A}_{2}^{L}\right)\right), \min \left(H_{2}\left(\widetilde{A}_{1}^{L}\right), H_{2}\left(\widetilde{A}_{2}^{L}\right)\right)\right)\right) \\
& k \widetilde{A_{1}}=\left(k \times a_{11}^{U}, k \times a_{12}^{U}, k \times a_{13^{\prime}}^{U}, k \times a_{14}^{U} ; H_{1}\left(\widetilde{A}_{1}^{U}\right), H_{2}\left(\widetilde{A}_{1}^{U}\right)\right),\left(k \times a_{11}^{L}, k \times a_{12^{\prime}}^{L}, k\right. \\
& \left.\times a_{13}^{L}, k \times a_{14}^{L} ; H_{1}\left(\widetilde{A}_{1}^{L}\right), H_{2}\left(\widetilde{A}_{1}^{L}\right)\right) \\
& \frac{\widetilde{A}_{1}}{k}=\left(\frac{1}{k} \times a_{11}^{U}, \frac{1}{k} \times a_{12}^{U}, \frac{1}{k} \times a_{13}^{U}, \frac{1}{k} \times a_{14}^{U} ; H_{1}\left(\widetilde{A}_{1}^{U}\right), H_{2}\left(\widetilde{A}_{1}^{U}\right)\right),\left(\frac{1}{k} \times a_{11}^{L}, \frac{1}{k} \times a_{12}^{L}, \frac{1}{k}\right. \\
& \left.\times a_{13}^{L}, \frac{1}{k} \times a_{14}^{L} ; H_{1}\left(\widetilde{A}_{1}^{L}\right), H_{2}\left(\widetilde{A}_{1}^{L}\right)\right)
\end{aligned}
$$

However, the linguistic term sets under the hesitancy are widely used for explaining the effects of consensus among some of the decision makers. In several cases, some experts prefer to appoint the same scales while others select the different choices. To provide more flexible and certain results from them, linguistic terms with the hesitancy could be considered to collect the linguistic scales for the criteria and alternatives. Accordingly, the linguistic model $S=\left\{S_{0}, S_{1}, \ldots, S_{t}\right\}$ and context-free grammar $G_{H}=\left(V_{N}, V_{T}, I, P\right)$ are defined [71].

Where

$$
\begin{gathered}
V_{N}=\{\langle\text { primary term }\rangle,\langle\text { composite term }\rangle,\langle\text { unary term }\rangle,\langle\text { binary term }\rangle,\langle\text { conjunction }\rangle\}, \\
V_{T}=\left\{\text { lower than, greater than, at least, at most, between, and }, S_{0}, S_{1}, \ldots, S_{t}\right\}, \\
I \in V_{N}, \\
P=\{I::=\langle\text { primary term }\rangle \mid\langle\text { composite term }\rangle,\langle\text { composite term }\rangle \\
::=\langle\text { composite term }\rangle\langle\text { primary term }\rangle \\
\mid\langle\text { binary relation }\rangle\langle\text { primary term }\rangle\langle\text { conjunction }\rangle\langle\text { primary term }\rangle, \\
\langle\text { primary term }\rangle::=S_{0}\left|S_{1}\right| \ldots \mid S_{t}, \\
\langle\text { unary relation }\rangle::=\text { lower than } \mid \text { greater than } \mid \text { at least } \mid \text { at most, } \\
\langle\text { binary relation }\rangle::=\text { between, } \\
\langle\text { conjunction }\rangle::=\text { and }\} .
\end{gathered}
$$

Also, hesitant fuzzy linguistic term set is $h_{S}=\left\{S_{i}, S_{i+1}, \ldots, S_{j}\right\}$. 


\section{Appendix B. Methodology}

The steps of IT2 fuzzy DEMATEL are summarized as

Step 1: The linguistic scales are provided for the relation matrix and their fuzzy numbers are used for the initial direct-relation fuzzy matrix $\widetilde{Z}$ is generated by using the average scores. This condition is detailed on the Equations (A9) and (A10).

$$
\begin{gathered}
\widetilde{Z}=\left[\begin{array}{ccccc}
0 & \widetilde{z}_{12} & \cdots & \cdots & \widetilde{z}_{1 n} \\
\widetilde{z}_{21} & 0 & \cdots & \cdots & \widetilde{z}_{2 n} \\
\vdots & \vdots & \ddots & \cdots & \cdots \\
\vdots & \vdots & \vdots & \ddots & \vdots \\
\widetilde{z}_{n 1} & \widetilde{z}_{n 2} & \cdots & \cdots & 0
\end{array}\right] \\
\widetilde{Z}=\frac{\widetilde{Z}^{1}+\widetilde{Z}^{2}+\widetilde{Z}^{3}+\ldots \widetilde{Z}^{n}}{n}
\end{gathered}
$$

Step 2: Normalized procedure is applied for the normalized direct relation matrix with the Formulas (A11)-(A13).

$$
\begin{aligned}
& \widetilde{X}=\left[\begin{array}{ccccc}
\widetilde{x}_{11} & \widetilde{x}_{12} & \ldots & \ldots & \widetilde{x}_{1 n} \\
\widetilde{x}_{21} & \widetilde{x}_{22} & \ldots & \ldots & \widetilde{x}_{2 n} \\
\vdots & \vdots & \ddots & \ldots & \ldots \\
\vdots & \vdots & \vdots & \ddots & \vdots \\
\widetilde{x}_{n 1} & \widetilde{x}_{n 2} & \ldots & \ldots & \widetilde{x}_{n n}
\end{array}\right] \\
& \widetilde{x}_{i j}=\frac{\widetilde{z}_{i j}}{r} \\
& =\left(\frac{Z_{a_{i j}}}{r}, \frac{Z_{b_{i j}^{\prime}}}{r}, \frac{Z_{c_{i j}^{\prime}}}{r}, \frac{Z_{d_{i j}}}{r} ; H_{1}\left(z_{i j}^{U}\right), H_{2}\left(z_{i j}^{U}\right)\right),\left(\frac{Z_{e_{i j}^{\prime}}}{r}, \frac{Z_{f_{i j}}}{r}, \frac{Z_{g_{i j}^{\prime}}}{r}, \frac{Z_{h_{i j}^{\prime}}}{r} ; H_{1}\left(z_{i j}^{L}\right), H_{2}\left(z_{i j}^{L}\right)\right) \\
& r=\max \left(\max _{1 \leq i \leq n} \sum_{j=1}^{n} Z_{\dot{d}_{i j^{\prime}}} \max _{1 \leq i \leq n} \sum_{j=1}^{n} Z_{d_{i j}}\right)
\end{aligned}
$$

Step 3: Total relation matrix is constructed by the Equations (A14)-(A18)

$$
\begin{aligned}
& X_{a}=\left[\begin{array}{ccccc}
0 & a^{\prime}{ }_{12} & \cdots & \cdots & a^{\prime}{ }_{1 n} \\
a^{\prime}{ }_{21} & 0 & \cdots & \cdots & a^{\prime}{ }_{2 n} \\
\vdots & \vdots & \ddots & \cdots & \cdots \\
\vdots & \vdots & \vdots & \ddots & \vdots \\
a_{n 1}^{\prime} & a_{n 2}^{\prime} & \cdots & \cdots & 0
\end{array}\right], \ldots, X_{h}=\left[\begin{array}{ccccc}
0 & h^{\prime}{ }_{12} & \cdots & \cdots & h^{\prime}{ }_{1 n} \\
h^{\prime}{ }_{21} & 0 & \cdots & \cdots & h^{\prime}{ }_{2 n} \\
\vdots & \vdots & \ddots & \cdots & \cdots \\
\vdots & \vdots & \vdots & \ddots & \vdots \\
h_{n 1}^{\prime} & h_{n 2}^{\prime} & \cdots & \cdots & 0
\end{array}\right] \\
& \widetilde{T}=\lim _{k \rightarrow \infty} \widetilde{X}+\widetilde{X}^{2}+\ldots+\widetilde{X}^{k} \\
& \widetilde{T}=\left[\begin{array}{ccccc}
\widetilde{t}_{11} & \widetilde{t}_{12} & \cdots & \cdots & \widetilde{t}_{1 n} \\
\widetilde{t}_{21} & \widetilde{t}_{22} & \cdots & \cdots & \widetilde{t}_{2 n} \\
\vdots & \vdots & \ddots & \cdots & \cdots \\
\vdots & \vdots & \vdots & \ddots & \vdots \\
\widetilde{t}_{n 1} & \widetilde{t}_{n 2} & \cdots & \cdots & \widetilde{t}_{n n}
\end{array}\right] \\
& \widetilde{t}_{i j}=\left(a^{\prime \prime}{ }_{i j}, b^{\prime \prime}{ }_{i j}, c^{\prime \prime}{ }_{i j}, d^{\prime \prime}{ }_{i j} ; H_{1}\left(\widetilde{t}_{i j}{ }^{U}\right), H_{2}\left(\widetilde{t}_{i j}{ }^{U}\right)\right),\left(e^{\prime \prime}{ }_{i j}, f^{\prime \prime}{ }_{i j}, g^{\prime \prime}{ }_{i j}, h^{\prime \prime}{ }_{i j} ; H_{1}\left(\widetilde{t}_{i j}{ }^{L}\right), H_{2}\left(\widetilde{t}_{i j}{ }^{L}\right)\right) \\
& {\left[a^{\prime \prime}{ }_{i j}\right]=X_{\mathfrak{a}} \times\left(I-X_{\mathfrak{a}}\right)^{-1}, \ldots,\left[h^{\prime \prime}{ }_{i j}\right]=X_{\hat{h}} \times\left(I-X_{h}\right)^{-1}}
\end{aligned}
$$


Step 4: Defuzzification procedure is applied to compute the impact and relation degrees of the criteria by using the Equations (A19)-(A22)

$$
\begin{gathered}
\operatorname{Def} f_{T}=\frac{\frac{\left(u_{U}-l_{U}\right)+\left(\beta_{U} \times m_{1 U}-l_{U}\right)+\left(\alpha_{U} \times m_{2 U}-l_{U}\right)}{4}+l_{U}+\left[\frac{\left(u_{L}-l_{L}\right)+\left(\beta_{L} \times m_{1 L}-l_{L}\right)+\left(\alpha_{L} \times m_{2 L}-l_{L}\right)}{4}+l_{L}\right]}{2} \\
\widetilde{D}_{i}^{\text {def }}=r=\left[\sum_{j=1}^{n} t_{i j}\right]_{n \times 1}=\left(r_{i}\right)_{n \times 1}=\left(t_{1}, \ldots, r_{i}, \ldots, r_{n}\right) \\
\widetilde{R}_{i}^{\text {def }}=y=\left[\sum_{i=1}^{n} t_{i j}\right]_{1 \times n}^{\prime}=\left(y_{j}\right)_{1 \times n}^{\prime}=\left(y_{1}, \ldots, y_{i}, \ldots, y_{n}\right)
\end{gathered}
$$

Step 5: The impact and relation map is constructed by using the values of $\left(\widetilde{D}_{i}+\widetilde{R}_{i}\right)^{\text {def }}$ and $\left(\widetilde{D}_{i}-\widetilde{R}_{i}\right)^{d e f}$. Where $\widetilde{D}_{i}^{\text {def }}$ is the sum of all vector rows and $\widetilde{R}_{i}^{d e f}$ is the sum of all vector columns. $\left(\widetilde{D}_{i}-\widetilde{R}_{i}\right)^{\text {def }}$ defines the influence degrees of each criterion while $\left(\widetilde{D}_{i}+\widetilde{R}_{i}\right)^{\text {def }}$ shows the importance degrees of criteria.

The steps of IT2 fuzzy TOPSIS are defined as

Step 6: Linguistic evaluations are provided from the experts and converted into the fuzzy numbers to construct the decision matrix with the Formulas (A23) and (A24).

$$
\begin{aligned}
& C_{1} C_{2} C_{3} \ldots C_{n} \\
& X_{i j}=\begin{array}{c}
A_{1} \\
A_{2} \\
A_{3} \\
\vdots \\
A_{m}
\end{array}\left[\begin{array}{ccccc}
x_{11} & x_{12} & x_{13} & \ldots & x_{1 n} \\
x_{21} & x_{22} & x_{23} & \ldots & x_{2 n} \\
x_{31} & x_{32} & x_{33} & \ldots & x_{3 n} \\
\vdots & \vdots & \ddots & \ldots & \vdots \\
x_{m 1} & x_{m 2} & x_{m 3} & \ldots & x_{m n}
\end{array}\right] \\
& X_{i j}=\frac{1}{K}\left[\sum_{e=1}^{n} X_{i j}{ }^{e}\right], i=1,2,3, \ldots, m
\end{aligned}
$$

where $X_{i j}$ are the aggregated fuzzy values of each criterion and $K$ is the number of decision makers.

Step 7: The defuzzification procedure is applied for providing the negative and positive ideal solutions with the defuzzified values. The ranking method for the trapezoidal interval type- 2 fuzzy sets is considered [56] and the formulas are given below (A25)-(A28).

$$
\begin{gathered}
\operatorname{Def}\left(x_{i j}\right)=\operatorname{Rank}\left(\widetilde{x}_{i j}\right)_{m \times n}\left(\widetilde{A}_{i}^{L}\right)+M_{2}\left(\widetilde{A}_{i}^{U}\right)+M_{2}\left(\widetilde{A}_{i}^{L}\right)+M_{3}\left(\widetilde{A}_{i}^{U}\right)+M_{3}\left(\widetilde{A}_{i}^{L}\right) \\
\left.=M_{1}\left(\widetilde{A}_{i}^{U}\right)+M_{1}\left(\widetilde{A}_{i}^{U}\right)+S_{4}\left(\widetilde{A}_{i}^{L}\right)\right) \\
-\frac{1}{4}\left(S_{1}\left(\widetilde{A}_{i}^{U}\right)+S_{1}\left(\widetilde{A}_{i}^{L}\right)+S_{2}\left(\widetilde{A}_{i}^{U}\right)+S_{2}\left(\widetilde{A}_{i}^{L}\right)+S_{3}\left(\widetilde{A}_{i}^{U}\right)+S_{3}\left(\widetilde{A}_{i}^{L}\right)+S_{4}\left(\widetilde{A}_{i}^{U}\right)+H_{1}\left(\widetilde{A}_{i}^{U}\right)+H_{1}\left(\widetilde{A}_{i}^{L}\right)+H_{2}\left(\widetilde{A}_{i}^{U}\right)+H_{2}\left(\widetilde{A}_{i}^{L}\right)\right. \\
\quad M_{p}\left(\widetilde{A}_{i}^{j}\right)=\left(a_{i p}^{j}+a_{i(p+1)}^{j}\right) / 2
\end{gathered}
$$

where $M_{p}\left(\widetilde{A}_{i}^{j}\right)$ is the average of the elements $a_{i p}^{j}$ and $a_{i(p+1)^{j}}^{j} 1 \leq p \leq 3$,

$$
S_{q}\left(\widetilde{A}_{i}^{j}\right)=\sqrt{\frac{1}{2} \sum_{k=q}^{q+1}\left(a_{i k}^{j}-\frac{1}{2} \sum_{k=q}^{q+1} a_{i k}^{j}\right)^{2}}
$$


where $S_{q}\left(\widetilde{A}_{i}^{j}\right)$ is the standard deviation of the elements $a_{i q}^{j}$ and $a_{i(q+1)^{\prime}}^{j}, 1 \leq q \leq 3$,

$$
S_{4}\left(\widetilde{A}_{i}^{j}\right)=\sqrt{\frac{1}{4} \sum_{k=1}^{4}\left(a_{i k}^{j}-\frac{1}{4} \sum_{k=1}^{4} a_{i k}^{j}\right)^{2}}
$$

$H_{p}\left(\widetilde{A}_{i}^{j}\right)$ is the membership value of the element $a_{i(p+1)}^{j}$ in the trapezoidal membership function $\widetilde{A}_{i}^{j}$ $1 \leq p \leq 2, j \in\{U, L\} 1 \leq i \leq n$.

Step 8: The positive- $\left(A^{+}\right)$and negative $\left(A^{-}\right)$ideal solutions are computed with the Formula (A29).

$$
A^{+}=\max \left(v_{1}, v_{2}, v_{3}, \ldots v_{n}\right) ; A^{-}=\min \left(v_{1}, v_{2}, v_{3}, \ldots v_{n}\right)
$$

where $v_{i j}$ is the weighted values of the defuzzified matrix.

Step 9: The values of $D^{+}$and $D^{-}$are calculated with Formulas (A30) and (A31)

$$
\begin{aligned}
& {D_{i}}^{+}=\sqrt{\sum_{i=1}^{m}\left(v_{i}-A_{i}\right)^{2}} \\
& D_{i}^{-}=\sqrt{\sum_{i=1}^{m}\left(v_{i}-A_{i}^{-}\right)^{2}}
\end{aligned}
$$

Step 10: The closeness coefficient $\left(C C_{i}\right)$ is computed with the Formula (A32)

$$
C C_{i}=\frac{D_{i}^{-}}{D_{i}^{+}+D_{i}^{-}}
$$




\section{Appendix C. Tables}

Table A1. The initial relation matrix.

\begin{tabular}{|c|c|c|c|c|c|}
\hline & $\mathrm{C} 1$ & $\mathrm{C} 2$ & C3 & C4 & C5 \\
\hline $\mathrm{C} 1$ & $\begin{array}{c}((0,0,0,0 ; 1,1) \\
(0,0,0,0 ; 0.90,0.90))\end{array}$ & $\begin{array}{c}((0.43,0.58,0.58,0.73 ; 1,1) \\
(0.48,0.58,0.58,0.68 ; 0.90,0.90))\end{array}$ & $\begin{array}{c}((0.43,0.58,0.58,0.73 ; 1,1) \\
(0.48,0.58,0.58,0.68 ; 0.90,0.90))\end{array}$ & $\begin{array}{c}((0.28,0.43,0.43,0.58 ; 1,1) \\
(0.33,0.43,0.43,0.53 ; 0.90,0.90))\end{array}$ & $\begin{array}{c}((0.50,0.65,0.65,0.78 ; 1,1) \\
(0.55,0.65,0.65,0.73 ; 0.90,0.90))\end{array}$ \\
\hline $\mathrm{C} 2$ & $\begin{array}{c}((0.50,0.65,0.65,0.78 ; 1,1) \\
(0.55,0.65,0.65,0.73 ; 0.90,0.90))\end{array}$ & $\begin{array}{c}((0,0,0,0 ; 1,1) \\
(0,0,0,0 ; 0.90,0.90))\end{array}$ & $\begin{array}{c}((0.28,0.43,0.43,0.58 ; 1,1) \\
(0.33,0.43,0.43,0.53 ; 0.90,0.90))\end{array}$ & $\begin{array}{c}((0.35,0.50,0.50,0.65 ; 1,1) \\
(0.40,0.50,0.50,0.60 ; 0.90,0.90))\end{array}$ & $\begin{array}{c}((0.43,0.58,0.58,0.73 ; 1,1) \\
(0.48,0.58,0.58,0.68 ; 0.90,0.90))\end{array}$ \\
\hline C3 & $\begin{array}{c}((0.35,0.50,0.50,0.65 ; 1,1) \\
(0.40,0.50,0.50,0.60 ; 0.90,0.90))\end{array}$ & $\begin{array}{c}((0.43,0.58,0.58,0.73 ; 1,1) \\
(0.48,0.58,0.58,0.68 ; 0.90,0.90))\end{array}$ & $\begin{array}{c}((0,0,0,0 ; 1,1) \\
(0,0,0,0 ; 0.90,0.90))\end{array}$ & $\begin{array}{c}((0.35,0.50,0.50,0.65 ; 1,1) \\
(0.40,0.50,0.50,0.60 ; 0.90,0.90))\end{array}$ & $\begin{array}{c}((0.28,0.43,0.43,0.58 ; 1,1) \\
(0.33,0.43,0.43,0.53 ; 0.90,0.90))\end{array}$ \\
\hline $\mathrm{C} 4$ & $\begin{array}{c}((0.43,0.58,0.58,0.73 ; 1,1) \\
(0.48,0.58,0.58,0.68 ; 0.90,0.90))\end{array}$ & $\begin{array}{c}((0.58,0.73,0.73,0.85 ; 1,1) \\
(0.63,0.73,0.73,0.80 ; 0.90,0.90))\end{array}$ & $\begin{array}{c}((0.50,0.65,0.65,0.78 ; 1,1) \\
(0.55,0.65,0.65,0.73 ; 0.90,0.90))\end{array}$ & $\begin{array}{c}((0,0,0,0 ; 1,1) \\
(0,0,0,0 ; 0.90,0.90))\end{array}$ & $\begin{array}{c}((0.43,0.58,0.58,0.73 ; 1,1) \\
(0.48,0.58,0.58,0.68 ; 0.90,0.90))\end{array}$ \\
\hline C5 & $\begin{array}{c}((0.43,0.58,0.58,0.73 ; 1,1) \\
(0.48,0.58,0.58,0.68 ; 0.90,0.90))\end{array}$ & $\begin{array}{c}((0.43,0.58,0.58,0.73 ; 1,1) \\
(0.48,0.58,0.58,0.68 ; 0.90,0.90))\end{array}$ & $\begin{array}{c}((0.35,0.50,0.50,0.65 ; 1,1) \\
(0.40,0.50,0.50,0.60 ; 0.90,0.90))\end{array}$ & $\begin{array}{c}((0.28,0.43,0.43,0.58 ; 1,1) \\
(0.33,0.43,0.43,0.53 ; 0.90,0.90))\end{array}$ & $\begin{array}{c}((0,0,0,0 ; 1,1) \\
(0,0,0,0 ; 0.90,0.90))\end{array}$ \\
\hline
\end{tabular}

Table A2. The normalized relation matrix.

\begin{tabular}{|c|c|c|c|c|c|}
\hline & C1 & C2 & C3 & $\mathrm{C} 4$ & C5 \\
\hline C1 & $\begin{array}{c}((0,0,0,0 ; 1,1) \\
(0,0,0,0 ; 0.90,0.90))\end{array}$ & $\begin{array}{c}((0.14,0.19,0.19,0.23 ; 1,1) \\
(0.15,0.19,0.19,0.22 ; 0.90,0.90))\end{array}$ & $\begin{array}{c}((0.14,0.19,0.19,0.23 ; 1,1) \\
(0.15,0.19,0.19,0.22 ; 0.90,0.90))\end{array}$ & $\begin{array}{c}((0.09,0.14,0.14,0.19 ; 1,1) \\
(0.10,0.14,0.14,0.17 ; 0.90,0.90))\end{array}$ & $\begin{array}{c}((0.16,0.21,0.21,0.25 ; 1,1) \\
(0.18,0.21,0.21,0.23 ; 0.90,0.90))\end{array}$ \\
\hline $\mathrm{C} 2$ & $\begin{array}{c}((0.16,0.21,0.21,0.25 ; 1,1) \\
(0.18,0.21,0.21,0.23 ; 0.90,0.90))\end{array}$ & $\begin{array}{c}((0,0,0,0 ; 1,1) \\
(0,0,0,0 ; 0.90,0.90))\end{array}$ & $\begin{array}{c}((0.09,0.14,0.14,0.19 ; 1,1) \\
(0.10,0.14,0.14,0.17 ; 0.90,0.90))\end{array}$ & $\begin{array}{c}((0.11,0.16,0.16,0.21 ; 1,1) \\
(0.13,0.16,0.16,0.19 ; 0.90,0.90))\end{array}$ & $\begin{array}{c}((0.14,0.19,0.19,0.23 ; 1,1) \\
(0.15,0.19,0.19,0.22 ; 0.90,0.90))\end{array}$ \\
\hline C3 & $\begin{array}{c}((0.11,0.16,0.16,0.21 ; 1,1) \\
(0.13,0.16,0.16,0.19 ; 0.90,0.90))\end{array}$ & $\begin{array}{c}((0.14,0.19,0.19,0.23 ; 1,1) \\
(0.15,0.19,0.19,0.22 ; 0.90,0.90))\end{array}$ & $\begin{array}{c}((0,0,0,0 ; 1,1) \\
(0,0,0,0 ; 0.90,0.90))\end{array}$ & $\begin{array}{c}((0.11,0.16,0.16,0.21 ; 1,1) \\
(0.13,0.16,0.16,0.19 ; 0.90,0.90))\end{array}$ & $\begin{array}{c}((0.09,0.14,0.14,0.19 ; 1,1) \\
(0.10,0.14,0.14,0.17 ; 0.90,0.90))\end{array}$ \\
\hline C4 & $\begin{array}{c}((0.14,0.19,0.19,0.23 ; 1,1) \\
(0.15,0.19,0.19,0.22 ; 0.90,0.90))\end{array}$ & $\begin{array}{c}((0.19,0.23,0.23,0.27 ; 1,1) \\
(0.20,0.23,0.23,0.26 ; 0.90,0.90))\end{array}$ & $\begin{array}{c}((0.16,0.21,0.21,0.26 ; 1,1) \\
(0.18,0.21,0.21,0.24 ; 0.90,0.90))\end{array}$ & $\begin{array}{c}((0,0,0,0 ; 1,1) \\
(0,0,0,0 ; 0.90,0.90))\end{array}$ & $\begin{array}{c}((0.14,0.19,0.19,0.23 ; 1,1) \\
(0.15,0.19,0.19,0.22 ; 0.90,0.90))\end{array}$ \\
\hline C5 & $\begin{array}{c}((0.14,0.19,0.19,0.23 ; 1,1) \\
(0.15,0.19,0.19,0.22 ; 0.90,0.90))\end{array}$ & $\begin{array}{c}((0.14,0.19,0.19,0.23 ; 1,1) \\
(0.15,0.19,0.19,0.22 ; 0.90,0.90))\end{array}$ & $\begin{array}{c}((0.11,0.16,0.16,0.21 ; 1,1) \\
(0.13,0.16,0.16,0.19 ; 0.90,0.90))\end{array}$ & $\begin{array}{c}((0.09,0.14,0.14,0.19 ; 1,1) \\
(0.10,0.14,0.14,0.17 ; 0.90,0.90))\end{array}$ & $\begin{array}{c}((0,0,0,0 ; 1,1) \\
(0,0,0,0 ; 0.90,0.90))\end{array}$ \\
\hline
\end{tabular}


Table A3. The total relation matrix.

\begin{tabular}{cccccc}
\hline & C1 & C2 & C3 & C5 & \\
\hline \multirow{2}{*}{ C1 } & $((0.13,0.38,0.38,1.62 ; 1,1)$, & $((0.26,0.55,0.55,1.87 ; 1,1)$, & $((0.24,0.51,0.51,1.74 ; 1,1)$, & $((0.18,0.44,0.44,1.58 ; 1,1)$, & $((0.26,0.54,0.54,1.79 ; 1,1)$, \\
& $(0.18,0.38,0.38,0.88 ; 0.90,0.90))$ & $(0.33,0.55,0.55,1.09 ; 0.90,0.90))$ & $(0.30,0.51,0.51,1.02 ; 0.90,0.90))$ & $(0.24,0.44,0.44,0.90 ; 0.90,0.90))$ & $(0.33,0.54,0.54,1.05 ; 0.90,0.90))$ \\
\hline \multirow{2}{*}{ C2 } & $((0.26,0.55,0.55,1.79 ; 1,1)$, & $((0.13,0.39,0.39,1.65 ; 1,1)$, & $((0.20,0.47,0.47,1.68 ; 1,1)$, & $((0.19,0.45,0.45,1.56 ; 1,1)$, & $((0.24,0.52,0.52,1.75 ; 1,1)$, \\
& $(0.33,0.55,0.55,1.05 ; 0.90,0.90))$ & $(0.19,0.39,0.39,0.89 ; 0.90,0.90))$ & $(0.26,0.47,0.47,0.97 ; 0.90,0.90))$ & $(0.25,0.45,0.45,0.90 ; 0.90,0.90))$ & $(0.31,0.52,0.52,1.02 ; 0.90,0.90))$ \\
\hline \multirow{2}{*}{ C3 } & $((0.22,0.49,0.49,1.70 ; 1,1)$, & $((0.24,0.52,0.52,1.78 ; 1,1)$, & $((0.10,0.33,0.33,1.47 ; 1,1)$, & $((0.19,0.43,0.43,1.51 ; 1,1)$, & $((0.19,0.46,0.46,1.66 ; 1,1)$, \\
& $(0.28,0.49,0.49,0.99 ; 0.90,0.90))$ & $(0.31,0.52,0.52,1.04 ; 0.90,0.90))$ & $(0.15,0.33,0.33,0.79 ; 0.90,0.90))$ & $(0.24,0.43,0.43,0.87 ; 0.90,0.90))$ & $(0.25,0.46,0.46,0.95 ; 0.90,0.90))$ \\
\hline \multirow{2}{*}{ C4 } & $((0.27,0.58,0.58,1.95 ; 1,1)$, & $((0.32,0.64,0.64,2.05 ; 1,1)$, & $((0.28,0.57,0.57,1.90 ; 1,1)$, & $((0.11,0.35,0.35,1.54 ; 1,1)$, & $((0.26,0.57,0.57,1.92 ; 1,1)$, \\
& $(0.34,0.58,0.58,1.14 ; 0.90,0.90))$ & $(0.39,0.64,0.64,1.21 ; 0.90,0.90))$ & $(0.34,0.57,0.57,1.11 ; 0.90,0.90))$ & $(0.17,0.35,0.35,0.83 ; 0.90,0.90))$ & $(0.34,0.57,0.57,1.12 ; 0.90,0.90))$ \\
\hline \multirow{2}{*}{ C5 } & $((0.24,0.52,0.52,1.75 ; 1,1)$, & $((0.25,0.533,0.53,1.81 ; 1,1)$, & $((0.21,0.47,0.47,1.67 ; 1,1)$, & $((0.17,0.42,0.42,1.52 ; 1,1)$, & $((0.11,0.35,0.35,1.53 ; 1,1)$, \\
& $(0.30,0.52,0.52,1.02 ; 0.90,0.90))$ & $(0.31,0.53,0.53,1.06 ; 0.90,0.90))$ & $(0.27,0.47,0.47,0.97 ; 0.90,0.90))$ & $(0.23,0.42,0.42,0.87 ; 0.90,0.90))$ & $(0.17,0.35,0.35,0.82 ; 0.90,0.90))$ \\
\hline
\end{tabular}

Source: Authors' calculations.

Table A4. The decision matrix.

\begin{tabular}{cccccc}
\hline & A1 & A2 & A3 & A4 & A5 \\
\hline \multirow{2}{*}{ C1 } & $((0.70,0.87,0.87,0.97 ; 1,1)$, & $((0.6,0.85,0.85,0.75 ; 1,1)$, & $((0.6,0.80,0.80,0.95 ; 1,1)$, & $((0.40,0.60,0.60,0.80 ; 1,1)$, \\
& $(0.78,0.87,0.87,0.92 ; 0.90,0.90))$ & $(0.7,0.8,0.8,0.88 ; 0.90,0.90))$ & $(0.7,0.8,0.8,0.88 ; 0.90,0.90))$ & $(0.50,0.60,0.60,0.70 ; 0.90,0.90))$ & $(0.6,0.7,0.7,0.78 ; 0.90,0.90))$ \\
\hline \multirow{2}{*}{ C2 } & $((0.5,0.7,0.7,0.90 ; 1,1)$, & $((0.40,0.75,0.75,0.65 ; 1,1)$, & $((0.30,0.50,0.50,0.70 ; 1.00,1.00)$, & $((0.30,0.50,0.50,0.70 ; 1.00,1.00)$, & $((0.70,0.90,0.90,1.00 ; 1,1)$, \\
& $(0.6,0.7,0.7,0.80 ; 0.90,0.90))$ & $(0.50,0.60,0.60,0.70 ; 0.90,0.90)$ & $(0.40,0.50,0.50,0.60 ; 0.90,0.90))$ & $(0.40,0.50,0.50,0.60 ; 0.90,0.90))$ & $(0.80,0.90,0.90,0.95 ; 0.90,0.90))$ \\
\hline \multirow{2}{*}{ C3 } & $((0.70,0.87,0.87,0.97 ; 1,1)$, & $((0.40,0.75,0.75,0.83 ; 1,1)$, & $((0.30,0.50,0.50,0.70 ; 1.00,1.00)$, & $((0.20,0.40,0.40,0.60 ; 1.00,1.00)$, & $((0.40,0.60,0.60,0.80 ; 1,1)$, \\
& $(0.78,0.87,0.87,0.92 ; 0.90,0.90))$ & $(0.50,0.60,0.60,0.70 ; 0.90,0.90)$ & $(0.40,0.50,0.50,0.60 ; 0.90,0.90))$ & $(0.30,0.40,0.40,0.50 ; 0.90,0.90))$ & $(0.50,0.60,0.60,0.70 ; 0.90,0.90))$ \\
\hline \multirow{2}{*}{ C4 } & $((0.80,0.95,0.95,1.00 ; 1.00,1.00)$, & $((0.40,0.75,0.75,0.83 ; 1,1)$, & $((0.40,0.60,0.60,0.80 ; 1,1)$, & $((0.50,0.70,0.70,0.90 ; 1,1)$, & $((0.70,0.87,0.87,0.97 ; 1,1)$, \\
& $(0.88,0.95,0.95,0.98 ; 0.90,0.90))$ & $(0.50,0.60,0.60,0.70 ; 0.90,0.90)$ & $(0.50,0.60,0.60,0.70 ; 0.90,0.90))$ & $(0.60,0.70,0.70,0.80 ; 0.90,0.90)$ & $(0.78,0.87,0.87,0.92 ; 0.90,0.90))$ \\
\hline \multirow{2}{*}{ C5 } & $((0.30,0.50,0.50,0.70 ; 1.00,1.00)$, & $((0.30,0.75,0.75,0.70 ; 1.00,1.00)$, & $((0.30,0.50,0.50,0.70 ; 1.00,1.00)$, & $((0.20,0.40,0.40,0.60 ; 1.00,1.00)$, & $((0.70,0.87,0.87,0.97 ; 1,1)$, \\
& $(0.40,0.50,0.50,0.60 ; 0.90,0.90))$ & $(0.40,0.50,0.50,0.60 ; 0.90,0.90))$ & $(0.40,0.50,0.50,0.60 ; 0.90,0.90))$ & $(0.30,0.40,0.40,0.50 ; 0.90,0.90))$ & $(0.78,0.87,0.87,0.92 ; 0.90,0.90))$ \\
\hline
\end{tabular}




\section{References}

1. Prahalad, C.K.; Ramaswamy, V. Co-opting Customer Competence. Harv. Bus. Rev. 2000, 78, 79-90.

2. Ple, L. Managing Multichannel Coordination in Retail Banking: The Influence of Customer Participation. Int. J. Bank Mark. 2006, 24, 327-345. [CrossRef]

3. Kenneth, R.E.; Arnold, T.J.; Grant, J.A. Combining Service and Sales at the Point of Customer Contact. J. Serv. Res. 1999, 2, 34-49.

4. Nambisan, S. Designing Virtual Customer Environments for New Product Development: Toward A Theory. Acad. Manag. Rev. 2002, 27, 392-413. [CrossRef]

5. Trott, P.; Hoecht, A.; Özdemir, S. New Service Development: Insights from An Explorative Study into the Turkish Retail Banking Sector. Innovation 2007, 9, 276-291.

6. Popoff, A.; Millet, D. Sustainable Life Cycle Design Using Constraint Satisfaction Problems and Quality Function Deployment. Procedia CIRP 2017, 61, 75-80. [CrossRef]

7. Chen, L.H.; Ko, W.C.; Yeh, F.T. Approach Based on Fuzzy Goal Programing and Quality Function Deployment for New Product Planning. Eur. J. Oper. Res. 2017, 259, 654-663. [CrossRef]

8. Wu, T.; Liu, X.; Liu, F. An interval type-2 fuzzy TOPSIS model for large scale group decision making problems with social network information. Inf. Sci. 2018, 432, 392-410. [CrossRef]

9. Wall, R.; Grafakos, S.; Gianoli, A.; Stavropoulos, S. Which policy instruments attract foreign direct investments in renewable energy? Clim. Policy 2019, 19, 59-72. [CrossRef]

10. Masud, M.H.; Ananno, A.A.; Arefin, A.M.; Ahamed, R.; Das, P.; Joardder, M.U. Perspective of biomass energy conversion in Bangladesh. Clean Technol. Environ. Policy 2019, 21, 1-13. [CrossRef]

11. Levieux, L.I.; Inthamoussou, F.A.; De Battista, H. Power dispatch assessment of a wind farm and a hydropower plant: A case study in Argentina. Energy Convers. Manag. 2019, 180, 391-400. [CrossRef]

12. Cetin, T.H.; Kanoglu, M.; Yanikomer, N. Cryogenic energy storage powered by geothermal energy. Geothermics 2019, 77, 34-40. [CrossRef]

13. Zafar, M.W.; Shahbaz, M.; Hou, F.; Sinha, A. From Nonrenewable to Renewable Energy and Its Impact on Economic Growth: The role of Research \& Development Expenditures in Asia-Pacific Economic Cooperation Countries. J. Clean. Prod. 2019, 212, 1166-1178.

14. Liang, Y.; Yu, B.; Wang, L. Costs and benefits of renewable energy development in China's power industry. Renew. Energy 2019, 131, 700-712. [CrossRef]

15. Ko, W.C. Construction of House of Quality for New Product Planning: A 2-Tuple Fuzzy Linguistic Approach. Comput. Ind. 2015, 73, 117-127. [CrossRef]

16. Hansen, K.; Mathiesen, B.V.; Skov, I.R. Full energy system transition towards $100 \%$ renewable energy in Germany in 2050. Renew. Sustain. Energy Rev. 2019, 102, 1-13. [CrossRef]

17. Garver, M.S. Improving the House of Quality with Maximum Difference Scaling. Int. J. Qual. Reliab. Manag. 2012, 29, 576-594. [CrossRef]

18. Dinçer, H.; Yüksel, S.; Pınarbaşı, F. SERVQUAL-Based Evaluation of Service Quality of Energy Companies in Turkey: Strategic Policies for Sustainable Economic Development. In The Circular Economy and Its Implications on Sustainability and the Green Supply Chain; IGI Global: Hershey, PA, USA, 2019; pp. 142-167.

19. Dinçer, H.; Yuksel, S. IT2-based Fuzzy Hybrid Decision Making Approach to Soft Computing. IEEE Access 2019, 7, 15932-15944. [CrossRef]

20. Keček, D.; Mikulić, D.; Lovrinčević, Ž. Deployment of renewable energy: Economic effects on the Croatian economy. Energy Policy 2019, 126, 402-410. [CrossRef]

21. Chuang, M.T.; Chang, S.Y.; Hsiao, T.C.; Lu, Y.R.; Yang, T.Y. Analyzing major renewable energy sources and power stability in Taiwan by 2030. Energy Policy 2019, 125, 293-306. [CrossRef]

22. Lin, B.; Chen, Y. Does electricity price matter for innovation in renewable energy technologies in China? Energy Econ. 2019, 78, 259-266. [CrossRef]

23. Chen, Y.; Wang, Z.; Zhong, Z. $\mathrm{CO}_{2}$ emissions, economic growth, renewable and non-renewable energy production and foreign trade in China. Renew. Energy 2019, 131, 208-216. [CrossRef]

24. Adiano, C.; Aleda, V.R. Beyond the House of Quality: Dynamic QFD. Benchmarking Qual. Manag. Technol. 1994, 1, 25-37. [CrossRef]

25. Wu, Q. Fuzzy Measurable House of Quality and Quality Function Deployment for Fuzzy Regression Estimation Problem. Expert Syst. Appl. 2011, 38, 14398-14406. [CrossRef] 
26. Li, Y.L.; Huang, M.; Chin, K.S.; Luo, X.G.; Han, Y. Integrating Preference Analysis and Balanced Scorecard to Product Planning House of Quality. Comput. Ind. Eng. 2011, 60, 256-268. [CrossRef]

27. Yazdani, M.; Zarate, P.; Coulibaly, A.; Zavadskas, E.K. A Group Decision Making Support System in Logistics and Supply Chain Management. Expert Syst. Appl. 2017, 88, 376-392. [CrossRef]

28. Wu, W.Y.; Qomariyah, A.; Sa, N.T.T.; Liao, Y. The Integration between Service Value and Service Recovery in the Hospitality Industry: An Application of QFD and ANP. Int. J. Hosp. Manag. 2018, 75, 48-57. [CrossRef]

29. Lin, T.; Ekanayake, A.; Gaweshan, L.S.; Hasan, Z.A. Ergonomics Product Development of over Bed Table for Bedridden Patients. Comput. Aided Des. Appl. 2016, 13, 538-548. [CrossRef]

30. Adinyira, E.; Kwofie, T.E.; Quarcoo, F. Stakeholder Requirements for Building Energy Efficiency in Mass Housing Delivery: The House of Quality Approach. Environ. Dev. Sustain. 2017, 20, 1-17. [CrossRef]

31. Seow, Y.; Goffin, N.; Rahimifard, S.; Woolley, E.A. Design for Energy Minimization Approach to Reduce Energy Consumption during the Manufacturing Phase. Energy 2016, 109, 894-905. [CrossRef]

32. Campisi, D.; Gitto, S.; Morea, D. An evaluation of energy and economic efficiency in residential buildings sector: A multi-criteria analisys on an Italian case study. Int. J. Energy Econ. Policy 2018, 8, 185-196.

33. Dinçer, H.; Yüksel, S.; Martínez, L. Balanced scorecard-based Analysis about European Energy Investment Policies: A hybrid hesitant fuzzy decision-making approach with Quality Function Deployment. Expert Syst. Appl. 2019, 115, 152-171. [CrossRef]

34. Abdullah, L.; Zulkifli, N. Integration of fuzzy AHP and interval type-2 fuzzy DEMATEL: An application to human resource management. Expert Syst. Appl. 2015, 42, 4397-4409. [CrossRef]

35. Hosseini, M.B.; Tarokh, M.J. Type-2 fuzzy set extension of DEMATEL method combined with perceptual computing for decision making. J. Ind. Eng. Int. 2013, 9, 10. [CrossRef]

36. Abdullah, L.; Zulkifli, N. A new DEMATEL method based on interval type-2 fuzzy sets for developing causal relationship of knowledge management criteria. Neural Comput. Appl. 2018, 1-17. [CrossRef]

37. Najib, L.; Ab Ghani, A.T.; Abdullah, L.; Ahmad, M.F. An Application of Coastal Erosion Decision Problem Using Interval Type-2 Fuzzy Dematel Method. J. Sustain. Sci. Manag. 2017, 12, 204-217.

38. Dinçer, H.; Yüksel, S.; Korsakienè, R.; Raišienė, A.G.; Bilan, Y. IT2 Hybrid Decision-Making Approach to Performance Measurement of Internationalized Firms in the Baltic States. Sustainability 2019, 11, 296. [CrossRef]

39. Tooranloo, H.S.; Azadi, M.H.; Sayyahpoor, A. Analyzing factors affecting implementation success of sustainable human resource management (SHRM) using a hybrid approach of FAHP and Type-2 fuzzy DEMATEL. J. Clean. Prod. 2017, 162, 1252-1265. [CrossRef]

40. Yüksel, S.; Dinçer, H.; Meral, Y. Financial Analysis of International Energy Trade: A Strategic Outlook for EU-15. Energies 2019, 12, 431. [CrossRef]

41. Liao, T.W. Two interval type 2 fuzzy TOPSIS material selection methods. Mater. Des. 2015, 88, 1088-1099. [CrossRef]

42. Dymova, L.; Sevastjanov, P.; Tikhonenko, A. An interval type-2 fuzzy extension of the TOPSIS method using alpha cuts. Knowl.-Based Syst. 2015, 83, 116-127. [CrossRef]

43. Sang, X.; Liu, X. An analytical solution to the TOPSIS model with interval type-2 fuzzy sets. Soft Comput. 2016, 20, 1213-1230. [CrossRef]

44. Zamri, N.; Abdullah, L. A new qualitative evaluation for an integrated interval type-2 fuzzy TOPSIS and MCGP. In Recent Advances on Soft Computing and Data Mining; Springer: Cham, Switzerland, 2014; pp. 79-88.

45. Abdullah, L.; Kamal, C.R.A.C. A New Integrating SAW-TOPSIS Based on Interval Type-2 Fuzzy Sets for Decision Making; IOS Press: Amsterdam, The Netherlands, 2016; pp. 45-50.

46. Yoon, K.; Hwang, C.L. TOPSIS (Technique for Order Preference by Similarity to Ideal Solution)—A Multiple Attribute Decision Making, w: MULTIPLE Attribute Decision Making-Methods and Applications, a State-of-the-at Survey; Springer: Berlin, Germany, 1981.

47. Finn, A. Investigating the non-linear effects of e-service quality dimensions on customer satisfaction. J. Retail. Consum. Serv. 2011, 18, 27-37. [CrossRef]

48. Gil, I.; Berenguer, G.; Cervera, A. The roles of service encounters, service value, and job satisfaction in achieving customer satisfaction in business relationships. Ind. Mark. Manag. 2008, 37, 921-939. [CrossRef]

49. Yoon, C. Antecedents of customer satisfaction with online banking in China: The effects of experience. Comput. Hum. Behav. 2010, 26, 1296-1304. [CrossRef]

50. Jones, C. Developing a scorecard for service quality. Manag. Serv. 2004, 48, 8-13. 
51. Grigoroudis, E.; Siskos, Y. A survey of customer satisfaction barometers: Some results from the transportation-communications sector. Eur. J. Oper. Res. 2004, 152, 334-353. [CrossRef]

52. Bei, L.T.; Shang, C.F. Building marketing strategies for state-owned enterprises against private ones based on the perspectives of customer satisfaction and service quality. J. Retail. Consum. Serv. 2006, 13, 1-13. [CrossRef]

53. Vivekanandana, L.; Jayasenab, S. Facilities offered by the Banks and Expectations of IT Savvy Banking Customers. Procedia Soc. Behav. Sci. 2012, 40, 576-583. [CrossRef]

54. Matos, C.R.; Carneiro, J.F.; Silva, P.P. Overview of Large-Scale Underground Energy Storage Technologies for Integration of Renewable Energies and Criteria for Reservoir Identification. J. Energy Storage 2019, 21, 241-258. [CrossRef]

55. Baykasoglu, A.; Gölcük, İ. Development of an interval type-2 fuzzy sets based hierarchical MADM model by combining DEMATEL and TOPSIS. Expert Syst. Appl. 2017, 70, 37-51. [CrossRef]

56. Chen, S.M.; Lee, L.W. Fuzzy multiple attributes group decision-making based on the interval type-2 TOPSIS method. Expert Syst. Appl. 2010, 37, 2790-2798. [CrossRef]

57. Nesticò, A.; Sica, F. The sustainability of urban renewal projects: A model for economic multi-criteria analysis. J. Prop. Investig. Financ. 2017, 35, 397-409. [CrossRef]

58. Joseph, M.; Stone, G. An empirical evaluation of US bank customer perceptions of the impact of technology on service delivery in the banking sector. Int. J. Retail Distrib. Manag. 2003, 31, 190-202. [CrossRef]

59. Celik, M.; Cebi, S.; Kahraman, C.; Er, I.D. An integrated fuzzy QFD model proposal on routing of shipping investment decisions in crude oil tanker market. Expert Syst. Appl. 2009, 36, 6227-6235. [CrossRef]

60. Dror, S.; Barad, M. House of Strategy (HOS): From strategic objectives to competitive priorities. Int. J. Prod. Res. 2006, 44, 3879-3895. [CrossRef]

61. Chen, C.T. Extensions of the TOPSIS for group decision-making under fuzzy environment. Fuzzy Sets Syst. 2000, 114, 1-9. [CrossRef]

62. Hsieh, T.Y.; Lu, S.T.; Tzeng, G.H. Fuzzy MCDM approach for planning and design tenders selection in public office buildings. Int. J. Proj. Manag. 2004, 22, 573-584. [CrossRef]

63. Erdogan, S.; Sayin, C. Selection of the most suitable Alternative fuel depending on the fuel characteristics and price by the hybrid MCDM method. Sustainability 2018, 10, 1583. [CrossRef]

64. Ball, D.; Simões Coelho, P.; Machás, A. The role of communication and trust in explaining customer loyalty: An extension to the ECSI model. Eur. J. Mark. 2004, 38, 1272-1293. [CrossRef]

65. Ford, W.Z. Customer expectations for interactions with service providers: Relationship versus encounter orientation and personalized service communication. J. Appl. Commun. Res. 2001, 29, 1-29. [CrossRef]

66. Ntanos, S.; Kyriakopoulos, G.; Chalikias, M.; Arabatzis, G.; Skordoulis, M. Public perceptions and willingness to pay for renewable energy: A case study from Greece. Sustainability 2018, 10, 687. [CrossRef]

67. Ntanos, S.; Kyriakopoulos, G.; Chalikias, M.; Arabatzis, G.; Skordoulis, M.; Galatsidas, S.; Drosos, D. A social assessment of the usage of renewable energy sources and its contribution to life quality: The case of an Attica urban area in Greece. Sustainability 2018, 10, 1414. [CrossRef]

68. Tsili, M.; Papathanassiou, S. A review of grid code technical requirements for wind farms. IET Renew. Power Gener. 2009, 3, 308-332. [CrossRef]

69. Kondziella, H.; Bruckner, T. Flexibility requirements of renewable energy based electricity systems-a review of research results and methodologies. Renew. Sustain. Energy Rev. 2016, 53, 10-22. [CrossRef]

70. Yam, F.K.; Hassan, Z. Innovative advances in LED technology. Microelectron. J. 2005, 36, 129-137. [CrossRef]

71. Finch, B.J. Customer expectations in online auction environments: An exploratory study of customer feedback and risk. J. Oper. Manag. 2007, 25, 985-997. [CrossRef]

72. Bevan, N. Quality in use: Meeting user needs for quality. J. Syst. Softw. 1999, 49, 89-96. [CrossRef]

73. Olsina, L.; Lafuente, G.; Rossi, G. Specifying quality characteristics and attributes for websites. In Web Engineering; Springer: Berlin, Germany, 2001; pp. 266-278.

(C) 2019 by the authors. Licensee MDPI, Basel, Switzerland. This article is an open access article distributed under the terms and conditions of the Creative Commons Attribution (CC BY) license (http://creativecommons.org/licenses/by/4.0/). 